BACKYARD LIVING: DEVELOPING A STRATEGY FOR CANADIAN MUNICIPALITIES TO IMPLEMENT LANEWAY HOUSING PROGRAMS THROUGH AN EVALUTION OF WESTERN CANADIAN PRECEDENTS

\author{
by \\ Brennan Finley \\ BRLS, Brock University, 2011 \\ A Major Research Paper \\ presented to Ryerson University \\ in partial fulfillment of the requirements for the degree of \\ Master of Planning \\ in \\ Urban Development \\ Toronto, Ontario, Canada, 2014
}

(C)Brennan Finley 2014 


\section{Author's Declaration}

I hereby declare that I am the sole author of this MRP. This is a true copy of the MRP, including any required final revisions.

I authorize Ryerson University to lend this MRP to other institutions or individuals for the purpose of scholarly research.

I further authorize Ryerson University to reproduce this MRP by photocopying or by other means, in total or in part, at the request of other institutions or individuals for the purpose of scholarly research.

I understand that my MRP may be made electronically available to the public. 


\title{
Backyard Living: Developing a Strategy for Canadian Municipalities to Implement Laneway Housing Programs through an Evaluation of Western Canadian Precedents.
}

\author{
CBrennan Finley 2014 \\ Master of Planning \\ in \\ Urban Development \\ Ryerson University
}

\begin{abstract}
The high cost of living in single-family neighbourhoods in major metropolitan cities throughout Canada is making single-family housing increasingly unaffordable. Due to the decreasing amount of developable land and the increasing urban population, the development of smaller housing forms including laneway housing are growing. Currently laneway housing is used throughout Western Canada to provide single-family living but at a more attainable price. Municipalities are realizing the benefits associated with laneway housing and its ability to maintain the character of single-family neighbourhoods and diversify municipal housing stocks. Utilising a mixed method approach of interviews and policy examination, an in-depth analysis of the City of North Vancouver, the District of North Vancouver, the District of West Vancouver and the City of Vancouver laneway housing programs uses a matrix to compare the liveability, compatibility with neighbours, suitability, effectiveness and administrative processes of each policy. Outcomes demonstrate that laneway housing is viable and that major barriers such as topography, patterns of subdivision and unequitable community engagement processes can be overcome by tailoring the policies criteria, design guidelines and administrative process.
\end{abstract}

Key Words: laneway housing; coach housing; planning; morphology; Metro Vancouver 


\section{Acknowledgments}

First and foremost I would like to thank my Mom for supporting me throughout this process and my Dad who was with me every step of the way. I would like to express my appreciation to Professor Shelagh McCartney, my research supervisor, for her patient guidance, constructive critiques and continual encouragement throughout this research process. I would also like to extend my thanks to Phil Chapman, my second reader for his valuable, in-depth suggestions during the planning and creation of this research paper. The combined willingness to give your time to helping me achieve my goals is much appreciated. Finally, I would like to thank my partner Alexandra for her moral support and understanding throughout the entire writing process. 


\section{Contents}

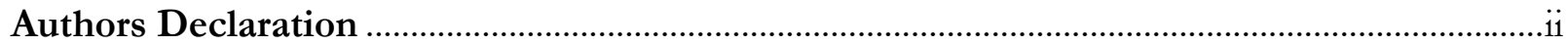

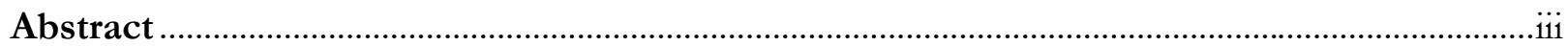

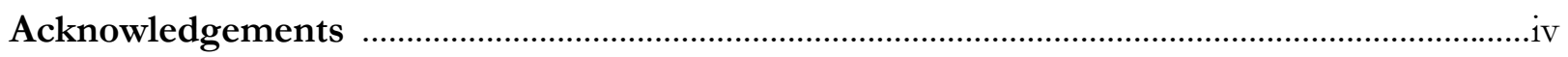

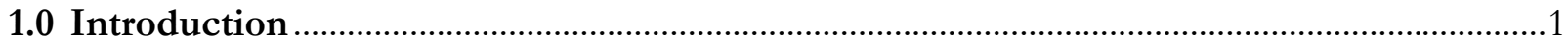

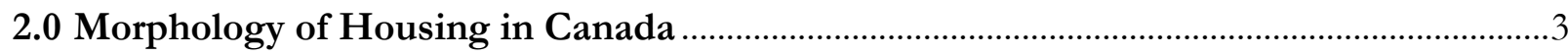

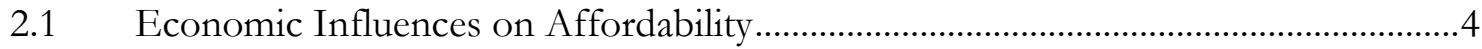

2.2 Changing Perceptions of How and Where to Live .....................................................

2.3 Impacts of Demographic Change on Housing ..............................................................

3.0 What are Laneway Houses and the Features Common to Policy Development?..............12

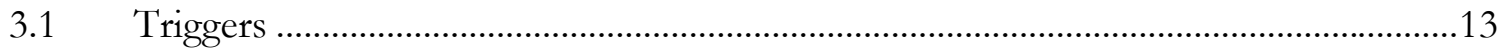

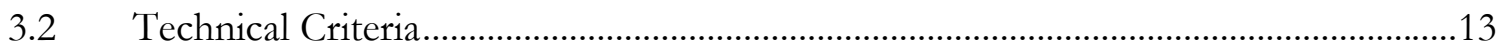

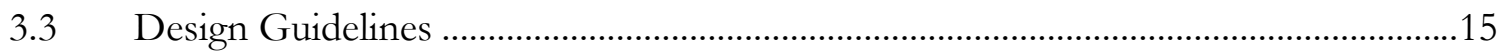

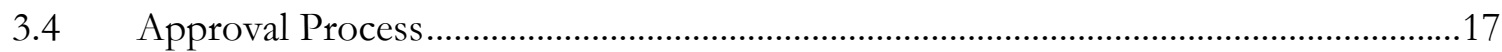

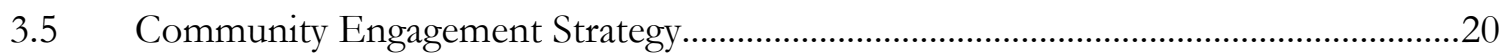

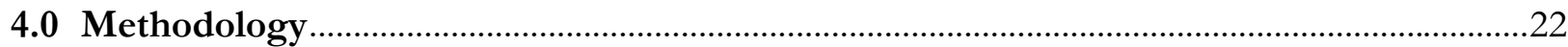

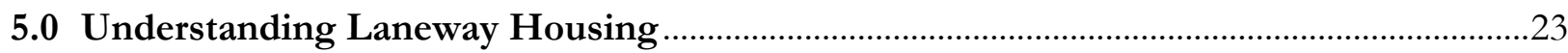

5.1 Laneway Housing in British Columbia: Indicators for Success ...................................26

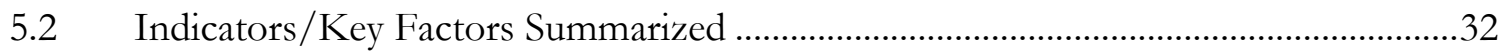

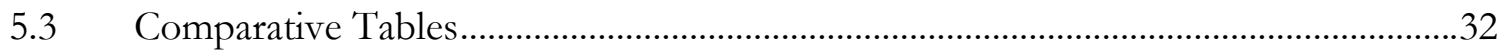

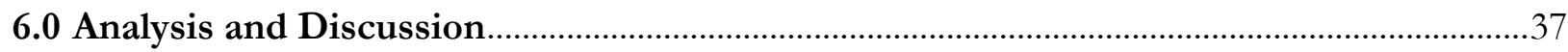

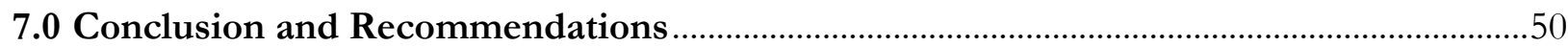

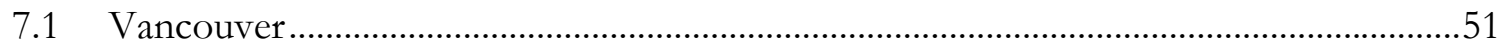

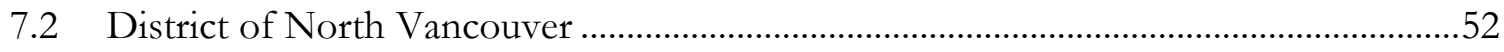

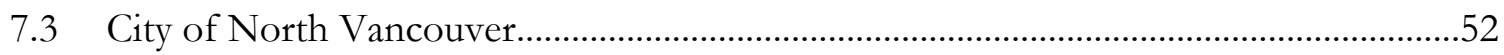

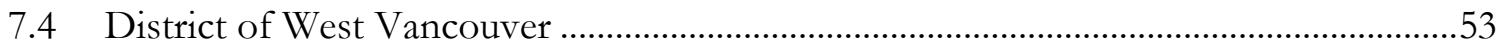

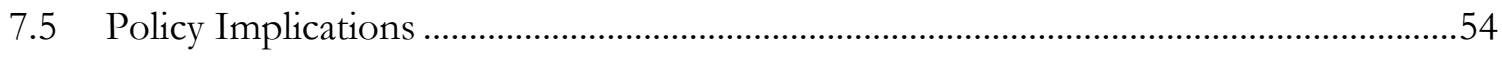

\section{Appendixes}

1. Appendix A - District of North Vancouver Coach House Demand Study .............................56

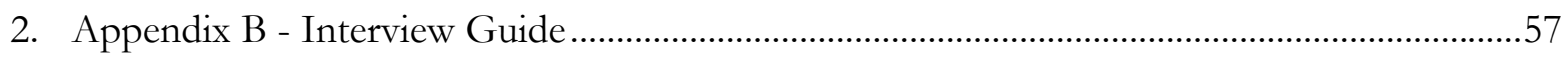

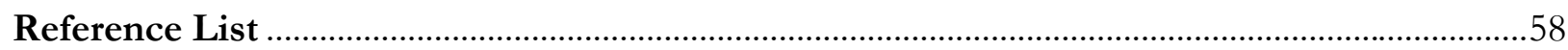




\section{List of Tables}

1. Demographic Characteristics, Statistics Canada, 2011.............................................................10

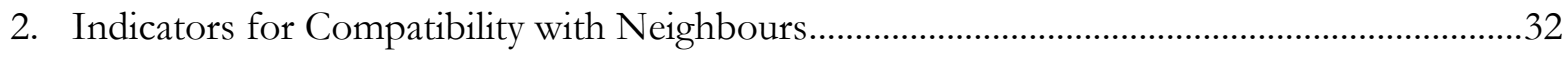

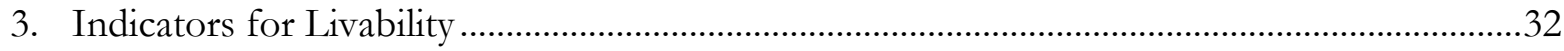

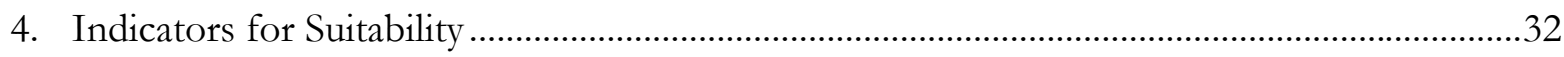

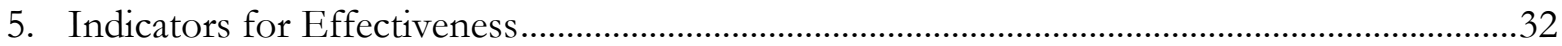

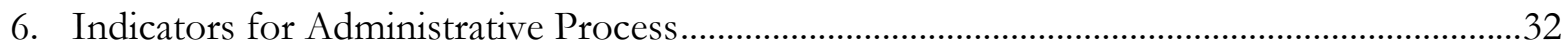

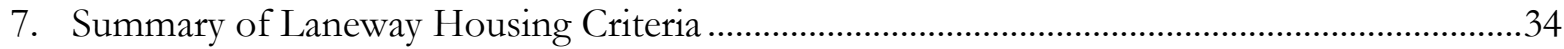

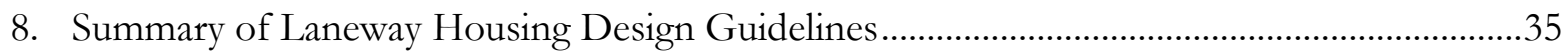

9. Summary of Laneway Housing Administrative Processes ..........................................................36 


\section{List of Figures}

A. Vancouver, C. o. Laneway Housing How-to-Guide . Vancouver. ..................................................17

B. Vancouver, C. o. Laneway Housing How-to-Guide . Vancouver. ....................................................17

C. Vancouver, D. o. Exploring Coach Houses in the DNV: A Discussion Paper.

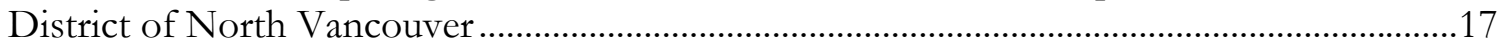

D. Maps, G. East Clayton Coach Houses.Surrey...............................................................................17

E. Finley, B. Coach House in the CNV.City of North Vancouver. .....................................................17

F. Ltd., F. H. Map of Canada. And Out, K. Map of Metro V ancouver.................................................28

G. Vancouver, C. o. Laneway Housing How-to-Guide . Vancouver. ………........................................37

H. Finley, B. Coach House in the CNV.City of North Vancouver. .....................................................46

I. Finley, B. Coach House in the CNV.City of North Vancouver. ....................................................46

J. Vancouver, C. o. Laneway House in Vancouver. City of Vancouver. .......................................46

K. Finley, B. Coach House in the CNV.City of North Vancouver. ...................................................48

L. Finley, B. Coach House in the CNV.City of North Vancouver. ....................................................48

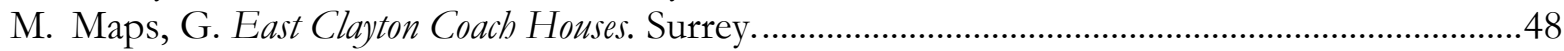

N. Finley, B. Summary Chart of Laneway Housing Policy Analysis ......................................................51 


\subsection{Introduction}

Housing throughout Canada has experienced major changes over the past two decades, evident in the physical built form across many metropolitan centres. Fluctuations in the local housing market, immigration and household trends, changing perceptions of ideal locations to live, environmental concerns and individual lifestyle choices have all played a role in changing the physical characteristics of homes in the country (Macdonald, 2010; Moore \& Skaburski 2004). The prevalence of smaller homes is increasing in communities across Canada as a way to tailor housing needs to current trends experienced within various jurisdictions and to address the increasing issues related to affordability and housing costs (CMHC, 2013; Metro Vancouver and Ministry of Community Services, 2007). As of 2011 over three-quarters $(76 \%)$ of households in condominiums were concentrated in ten metropolitan areas, with Toronto, Vancouver and Montreal accounting for more than half $(53 \%)$ of all condominium households in Canada (Statistics Canada, 2011). With approximately 1,300 laneway houses constructed in Vancouver alone in the past five years it becomes evident that the continuous construction of smaller units has and will continue to drive the housing market in metropolitan areas (Planner D, 2014). Different housing forms have varying effects on the urban fabric of the neighbourhoods that are experiencing the change. Condominiums or small lot land assembly development can change the lot pattern and building envelope of a neighbourhood and greatly impact the urban fabric of an area compared to laneway housing.

Laneway housing is also called coach housing, accessory dwelling units, carriage housing or backyard cottages. It has been used as a tool by municipalities to increase rental stock, diversify housing typologies, densify areas to make better use of major infrastructure investment, an economical solution to increases in density or build a stronger sense of community. There are many benefits associated with this form of housing including the ability to add density while maintaining the character of existing single-family neighbourhoods (similar building size and forms), increasing rental stock and making housing more affordable for various income brackets and providing options for seniors to downsize or young adults to experience single-family living, all of which has aided in its adoption. However, there have also been legitimate logistical and personal concerns raised by community groups and councillors regarding the impact coach housing has on their neighbourhood such as increased servicing costs for municipalities, loss of privacy due to overlook windows and upper floor balconies, additional density to single-family communities and changing the neighbourhood character of an established single-family area (City of Toronto Staff Report, 2006; 
Stinson \& Elslander, 2003; CMHC, 2009; District of Maple Ridge, 2007; Planner B, 2014). The strength of laneway housing is its ability to maintain the character of single family neighbourhoods that are experiencing pressure to increase density, or are experiencing rapidly rising house prices because additional options are provided to home owners outside of land assembly or completely redeveloping of their property into one large home.

Two questions will be examined throughout the course of this analysis. First, why is laneway housing a beneficial form of housing in major metropolitan cities? By examining current housing market trends, demographic factors and the changing perceptions of living it is clear that laneway housing can address many economic and cultural issues municipalities are currently experiencing. Second, this paper will examine how major metropolitan cities can develop and implement a laneway housing policy successfully. Each municipality is unique however by conducting a case study analysis of four laneway housing policies within British Columbia including; The City of Vancouver, The City of North Vancouver, the District of North Vancouver and the District of West Vancouver common processes and policy details may appear. Each municipality was selected based on how long they have had a laneway housing policy for in order to examine each policy at different stages. Quantitative and qualitative research methods are used to investigate the triggers which led to the development of the Laneway Housing policy in each jurisdiction, the technical criteria and physical characteristics of the policy, the overall approval processes, design guidelines and community engagement strategies (CMHC, 2009). This analysis will produce a matrix comparing the four municipalities laneway housing policies, analysis will focus on evaluating each policy against four laneway housing principles; compatibility with neighbour, liveability, suitability/effectiveness and approval process. This will help future laneway housing policy makers understand what facets (i.e. topography and housing goals) should be researched and studies when developing policy specific to their municipality. 


\subsection{Morphology of Housing in Canada}

Examining how the demand for smaller homes came to fruition in major Canadian cities provides more perspective on the impacts and role of laneway housing. Factors such as the affordability of homes and various economic elements have played immense roles in the development of smaller housing. The largest factor being the limited supply of land resources in metropolitan areas resulting in affordability issues and developers building 'up' rather than 'out' (Lucy \& Phillips, 2006). This has drastically changed the urban landscape of downtown areas, particularly in Vancouver and Toronto who have experienced major high-rise development as a result of increased density (Saunders \& Fishman, 2005).

Increases in the number of single people and decreases in the number of people getting married have impacted the type of home people seek to live in (Statistics Canada, 2011). As a result the number of one person households is increasing and the average household size is declining. High immigration rates, family dynamics and income levels are all important influences on the changes to the built-form of housing in Canada (Statistics Canada, 2011). Cultural perceptions of what is a 'desirable' way to live have also changed. For example, more people are interested in living close to work and less content on commuting long distances in their cars (Lucy \& Phillips, 2006), increasing demand thus driving up housing costs in urban areas. The 'pull' factor created by the culture of the downtown core draws various types of people to the area, all with varying housing needs, and has changed younger generations housing expectations - smaller, less impact on the environment and location based (Lucy \& Phillips, 2006). Finally there is planning rationale behind intensification and adding density to built-up areas in order to maximize efficiencies and increase urban sustainability (Lucy \& Phillips, 2006). Continually building out and urban sprawl requires additional servicing infrastructure whereas building up or conducting infill redevelopment can make use of existing infrastructure potentially not operating a full capacity.

Economic, demographic and cultural variables all impact the shape of our cities and can create a shift in the types of homes that are being built (Statistics Canada, 2011, Lucy \& Phillips, 2006, Hulchanski, 2010, Macdonald, 2010). Morphology is defined as the transformation of the urban fabric and is highly noticeable through changes to the physical built-form (Hulchanski, 2010). Various housing typologies make up a majority of the urban fabric in communities such as singlefamily, low-rise apartments, mid-rise and high-rise condominiums. Laneway housing has the ability 
to fit into the changing urban fabric of major cities and can offer a number of benefits to the community and city as a whole. The main benefit of laneway housing is the ability to keep the same 'feel' of a community while offering higher density options that are more 'hidden'. For example, if a single-family neighbourhood is feeling pressure to increase density a common option is to assemble land with adjacent neighbours and build either low-rise apartments or some form of a multiplex (duplex, triplex, fourplex, etc.). The scale of these new forms of housing within the existing neighbourhood can often impact the urban fabric of the neighbourhood by changing the streetscape and the pattern of subdivision in the area. However laneway houses are at a smaller scale, typically located behind the main dwelling and can provide similar density targets as row housing if you factor in the main house also having a secondary suite in the basement or at ground level. With many urban and suburban cities growing there is a need to find creative solutions to adding density in single-family neighbourhoods while maintaining the character of the area.

Density is happening. Major cities are growing. Changes will occur. It is up to the community, policy makers and politicians to determine the effect these changes will have on the urban fabric of their neighbourhoods. Laneway housing can provide another option to accommodate additional density on a smaller scale as opposed to mid and high-rise development. It can maintain the character of single-family neighbourhoods while alleviating the pressure of densification and large scale change.

\subsection{Economic Influences on Affordability}

Various economic factors have had major impacts on the morphology of housing and can be attributed to the dramatic changes seen in the urban fabric of our cities. Housing affordability is an issue that affects the city as a whole due to the rising cost of land in major cities such as Toronto and Vancouver (Macdonald, 2010). Evidence has been linked between housing costs and segregation among class types and their access to particular services. Hulchanski (2010) has found that Toronto is slowly developing into a three separate cities with higher income individuals living close to downtown near an abundance of services and lower income groups pushed to the edges of the city's boundaries due to the high costs of housing in the downtown. Vancouver tends to mirror Toronto's housing affordability with extremely high land values located in the downtown core and surrounding areas and suburbs having less expensive prices. Entire cities must be aware of this affordability issue and its impacts on the long term creation of inclusive and sustainable cities. To ensure this type of 
segregation does not persist municipalities must offer a variety of housing types in extremely high real estate markets.

Thus, the first economic factor that has had a large impact on smaller housing sizes is the increase cost of land in large Canadian cities (Macdonald, 2010). This has been particularly evident in the dramatic increase in prices of single-family homes in cities like Vancouver and Toronto who both experiences major housing booms (Macdonald, 2010). As this form of housing becomes more expensive homebuyers will look for lower-cost forms of housing including apartments, townhouses and multi-unit dwellings (Neptis Foundation, 2006). For example the average cost of a single-family home in Greater Vancouver is $\$ 927,300$ and in the GTA it is $\$ 555,500$ as of December 2013 (MLS, 2013).Knowing exactly why the cost of housing increased rapidly for both cities the past decade is not the focus of this paper however understanding some key influences that help create strong housing markets and drive housing prices in cities like Vancouver and Toronto is explored.

Positive or negative migration trends into major cities can have a similar effect on housing prices. As population numbers increase so does the demand for housing because land resources that are well serviced are limited so there are more people vying for the same type of home and there are fewer available. Thus population growth, often fueled by birth rates and immigration, can drive up the costs of all housing especially if a majority of that growth is occurring in the downtown area of a municipality where land supply is at a minimum.

Mortgage rates play a large role in affecting the cost of housing for potential home buyers. Many homeowners secure loans to in order to afford the type of home they desire which is typically based on one's annual income. Therefore if the annual mortgage rate is 3\% on a $\$ 400,000$ loan then the homeowner must pay $\$ 12,000$ in interest a year (assuming they are not paying down the principle during this time). When mortgage rates are low it allows a home owner to carry a larger mortgage for similar monthly payments. Low mortgage rates that were experienced in places like the Greater Toronto Area (GTA) following 2008 led to extremely high housing prices (Macdonald, 2010). The theory was that lowering the rate would stimulate the economy following the large financial crisis in the United States (Macdonald, 2010). The important facet of mortgage rates is that they can have large influences on the demand for housing by either allowing or restricting potential homebuyers to secure loans, sometimes resulting in increasing or decreasing housing prices. 
Employment rates can be a significant indicator of a city that has a strong workforce leading to high housing prices and the possible exploration of smaller housing units. Cities with high employment rates have been linked to higher net migration rates and thus increased the demand for housing (Neptis Foundation, 2006). People tend to move to areas with high employment rates with the hopes of finding a career, however this is not always the best indictor to use when determining housing price increases. Combining this information with other economic indicators such as migration, interest rates and single-family housing costs will identify strong housing markets and the likelihood of a municipality's need to explore alternative, smaller housing typologies. Housing costs are not only affected by variables that influence demand but also by the supply of houses that can change due to a number of reasons (Macdonald, 2006).

The amount of available land also has a drastic impact on the affordability of home ownership within major cities. As the demand and cost for housing increases builders and developers will attempt to meet that demand by constructing new homes. Builders and developers hope is to capture the potential profit in the market. If they see that housing prices are declining they are more likely to cut back on new housing completions in order to fill current housing stock and decrease future risk (Macdonald, 2006). The Ontario Growth Plan (2006), for example, has focused future development to 'existing built-up areas' in Ontario mainly in an attempt to protect green fields, reduce sprawl and increase density in established areas. British Columbia has The Local Government Act which aims to avoid sprawl and environmentally sensitive areas. Therefore the amount of easily developable land is at a minimum in major metropolitan cities and it becomes more economically advantageous for developers to build up (condominiums) instead of out (low-density, single-family). Since the supply of land and the supply of new construction starts impacts the prices and type of new homes that are being built the result is the creation of smaller dwelling units in strong housing markets.

Finally the issue of affordability can be greatly affected by rental rates, ratio to home cost and fluctuations in vacancy rates. With vacancy rates in the GTA and Metro Vancouver around $1.7 \%$, well below the national average of $2.8 \%$, there is demand for additional rental units (Stats Canada, 2012) in these jurisdictions. When this is combined with high rental rates in both markets it is assumed investment into additional rental construction would occur. However because the return on investment is low in the short term and there is minimal interest from most developers to become involved in long-term project management, thus construction of strictly rental buildings has 
not prospered in major cities (Pomeroy, 2001). Continually, housing markets are strong in the GTA and Metro Vancouver with growing financial incentive to build units at market rates. Low supply and high demand for rental in these cities has put pressure on the rental prices of current units, driving the price up. Laneway houses in many municipalities are used strictly for rental purposes and increasing rental stock is often the reason some jurisdictions adopt the policy in the first place. In other words, if laneway housing policies were implemented, additional rental properties would be developed by individual single family property owners and allow more people to enter into the housing market by increasing the supply of rental options.

The purpose of understanding various economic factors involved in land and housing development is to recognize why metropolitan areas such as the GTA and Metro Vancouver are experiencing changes in the built-form of their housing market. Due to the soaring cost of land in the Metro Vancouver and the GTA traditional single-family home ownership is not a realistic option for a majority of the population. Alternative options such as apartments, townhouses, and laneway houses are being explored more and more to increase affordability of housing to various income groups and ensure Hulchanski's (2010) income polarization model does not persist into the future through the integration of various income levels across Canada.

\subsection{Changing Perceptions of Where and How to Live}

At the turn of the $19^{\text {th }}$ century city crowding was seen as pervasive and oppressive, and strong efforts were made by planners, politicians and the development community to create more open space to escape the dense urban environment (Saunders \& Fishman, 2005). More recently, in the 'new fragmented city', politicians, city planners and urban designers see openness and sprawl as pervasive and oppressive, and density becomes the long-term goal because of decreased infrastructure costs and enhanced sustainability (Saunders \& Fishman, 2005). This ideology can be seen in provincial legislation with the Ontario Places to Grow Act which requires a majority of development to occur in built-up areas as opposed to green field development. This paper will not make an argument for or against sprawl, however the fact that today's culture is one that is more open to increased density and infill development is an influential shift in the acceptance of laneway housing in many Canadian municipalities.

Typically when people think of regions like Toronto and Vancouver they think of shops, restaurants, high-rise buildings, walking or taking some form of public transportation to get around, 
high living costs, people living in small spaces, proximity to jobs, a trendy place to associate yourself with and plenty of accessible amenities (Planner B, 2014). However, suburban communities found outside of these major metropolitan hubs are often associated with driving your car to get around, major highways and road systems, cheaper land and larger homes, reasonable cost of living and lower density to name a few. Due to the high growth rate in population of the GTA $(4.5 \%$ from 2006-2011) and the Metro Vancouver (4.4\% from 2006-2011) as well as the increasing strength of their housing markets, these areas are viewed by our society and newcomers as ideal places to live (Statistics Canada, 2011). Continuously, studies have found that as central cities gain population, their surrounding suburban population declines at a rate relative to the rate of growth in the central city (Lucy \& Phillips, 2006). The value of living close to work and near amenities has such a large significance that crowding (or increased density) is not something people seem to be overly concerned with (Lucy \& Phillips, 2006). The main concern appears to be finding affordable accommodations, in ideal locations, that allow an individual access to the many benefits that a 'big city' has to offer.

Where people want to live is important to understand when discussing laneway housing because it provides another housing option for middle income earners when searching for homes in desirable neighbourhoods. Transportation and the desire by many to avoid rush hour traffic, and instead take subways, buses or street cars has also played a role in creating a shift towards major city living. Large investments have been made in transit expansion in both Metro Vancouver and the GTA to make the city more accessible and to accommodate the needs of citizens. There are many noted benefits that accompany transit infrastructure such as the financial savings of not relying primarily on automobile ownership and the decreased impact on the environment when compared to automobiles (HDR, Greater Toronto Transportation Authority, 2008 \& Organisation for Economic Co-Operation and Development, 2009). There are still many individuals who enjoy driving and owning a car which is an ideology that is unlikely to completely change. However the benefits that are associated with transit investment are becoming more widely realized and drawing more people into metropolitan centres.

The influx of people into the GTA and Metro Vancouver, investments in transit and the creation of walkable communities have increased housing costs year over year for a decade and major cities must find ways to accommodate inhabitants varying income levels in order to maintain a healthy region. Attempts need to be made to integrate all income levels into one city because there 
is a greater possibility to maintain the health of a region and ensure equal access to services when compared to a fragmented city with low-income residents living with decreased access services (Hulchanski, 2010). Moreover, single-family living is still something many individuals, couples and families desire however high real estate costs often prevent this from occurring. Laneway housing can make home ownership affordable to middle income earners in high real estate markets and provide single-family living at an exceedingly reduced cost. Laneway homes can also be rental properties and thus they can provide a middle-income earner the ability to 'move-up' from a lowercost rental unit to one that they can still afford but provides them with more of the lifestyle they desire. This allows renters who desire ground-level living in a single family neighbourhood where there usually are few rental options a place to live to be an option (Planner B, 2014).

\subsection{Impacts of Demographic Change on Housing}

Economic factors are not the only catalysts that are having a significant impact on the types of homes being built in Metro Vancouver and the GTA. Demographic changes over the past decade have affected the housing market and changed the types of home developers are willing to build. Of the approximate 225,000 new immigrants admitted into Canada each year $62.5 \%$ decide to call Toronto, Vancouver or Montreal their home (Statistics Canada, 2011). More specifically, immigrant population in the GTA accounts for $46 \%$ of the total population while in Vancouver immigrants occupy 40\% of the population (Statistics Canada, 2011). Population totals in the GTA and Metro Vancouver are rising largely due to the influx of newcomers to the area all of which are bringing their way of life with them. For example, the Filipino population in Toronto has been linked to prolonged trends of renting among immigrants and often will seek to rent rather than own because of the practicality of living close to work (Thomas, 2011). However, the demands for rental units are usually filled through secondary markets due to the low number of purpose-built rentals in the GTA (Thomas, 2011). With such high housing prices in major metropolitan areas, newcomers that do seek to buy rather than rent bid on smaller units and drive the price of those units up. Therefore it seems more attractive for a developer to actually build smaller units to fill the demand of a growing population group.

Major cities in Canada are also starting to see a shift in the makeup of families and the number of single people occupying homes from a large portion of couples getting married to many waiting for later in life to start a family (See Table 1). These factors can impact the types of homes 
being built and often lead to the increase of smaller home construction in order to meet varying housing needs.

\begin{tabular}{|c|c|c|c|}
\hline \multicolumn{4}{|c|}{$\begin{array}{c}\% \text { of population over aged } 15 \text { years and } \\
\text { over who are single (never legally } \\
\text { married) }\end{array}$} \\
\hline & 2006 & 2011 & Change \\
\hline Toronto CMA & $30 \%$ & $34 \%$ & $4 \%$ \\
\hline Vancouver CMA & $29 \%$ & $36 \%$ & $7 \%$ \\
\hline
\end{tabular}

\begin{tabular}{lrrr}
\multicolumn{3}{c}{$\begin{array}{c}\% \\
\text { living as a couple (married or common } \\
\text { law) }\end{array}$} \\
\hline & 2006 & 2011 & Change \\
\hline Toronto CMA & $57 \%$ & $51 \%$ & $-6 \%$ \\
Vancouver CMA & $57 \%$ & $49 \%$ & $-8 \%$
\end{tabular}

\begin{tabular}{lccr}
\multicolumn{4}{c}{$\%$ of one-person households } \\
\hline & 2006 & 2011 & Change \\
\hline Toronto CMA & $23 \%$ & $31 \%$ & $8 \%$ \\
Vancouver CMA & $28 \%$ & $38 \%$ & $10 \%$
\end{tabular}

\begin{tabular}{lrrr}
\multicolumn{4}{c}{ Average household size } \\
\hline & 2006 & 2011 & Change \\
\hline Toronto CMA & 2.8 & 2.5 & -0.3 \\
Vancouver CMA & 2.6 & 2.2 & -0.4
\end{tabular}

Table 1: Demographic Characteristics, Statistics Canada, 2011

Several interesting observations can be made from this data. First, Vancouver and Toronto have similar martial and family-related trends and have experienced similar changes between 2006-2011. Second, the largest change over the past year related to household demographic factors is the number of one-person households, which has increased by $8 \%$ in Toronto and $10 \%$ in Vancouver. This increase has been reflected in the decrease in average household size for both CMA`s. Third, at the same time we are seeing a trend towards more people remaining single and not getting married (increase of 4\% on Toronto and 7\% in Vancouver) we are also seeing a decrease in the number of married or common-law couples living together (down 6\% in Toronto and $8 \%$ in Vancouver). In sum, these results show a similar relationship between the major metropolitan areas and the housing trends they are experiencing. These trends all point to changes in the physical characteristics of 
households in these areas. With smaller families and more single individuals the market is shifting towards smaller homes being built. 


\subsection{What are Laneway Houses and the Features Common to Policy Development?}

This section is meant to provide a rationale as to why many major Canadian cities, specifically Toronto and Vancouver, have seen a change in the physical urban fabric and physical built-form of their housing market. Economic, demographic and cultural factors have had immense impacts on the size, type and location of homes individuals' desire. Smaller homes are inevitable in these areas and laneway houses are being used throughout Metro Vancouver as a way to accommodate the shift in the market. Currently Toronto does not have policy in place to permit coach house development and current laneway homes that have been built are one-off, expensive, and took extremely long to get approved. This is because Toronto has stated in a staff report that laneways should only be used for vehicular access, inadequate space for the installation of new utilities resulting in high costs, impact on neighbouring properties is too great and increased City costs due to snow removal and garbage collection (City of Toronto, 2006). Arguments have been made for and against this form of development by Planners, Councillors, Developers and community members, and by examining the growing use of laneway houses and why they are important, a framework can be developed for the case study analysis.

A Laneway House, which are also commonly referred to as: a Coach House, Accessory Dwelling Unit, Carriage House, Detached Garden Suite or Backyard Cottage, can be defined as a detached secondary suite that is built in the rear yard of a detached single-family residential home. Laneway Houses are smaller in size and compliment the main residence by incorporating similar design standards and some form of additional parking (Maple Ridge, 2007). They can range in square footage from 500 to 1,000 square feet and in height from 1 to 2 stories depending on the size of the principle dwelling, but normally have no more than two bedrooms (District of North Vancouver, 2013). Laneway House design guidelines are used to guide aesthetic features such as: site planning, allocating private outdoor space, landscaped lane frontages, side yard setbacks, window placement, unit size and height of the Laneway House.

There are a number of steps that are taken into consideration before Laneway Housing policy can be adopted, each requiring in-depth research and analysis. CMHC (2009) outlined five themes when providing recommendations on incorporating Laneway Housing as a form of infill housing for municipalities including policy strategies, technical aspects, approval processes, design guidelines and community consultation. These will act as the backbone for this paper's policy 
analysis of current municipal laneway housing policies. A brief description of each theme based on stakeholder interviews can highlight important considerations for jurisdictions as well as provide a stronger understanding during the case study analysis.

\subsection{Triggers}

Triggers can be defined as the reasons why Laneway Housing was investigated as a potential form of infill housing in the first place. Rather than examining policy strategies which are outlined by CMHC (2009) as phases for policy implementation this paper aims to understand why Laneway Housing was being explored as a solution to begin with in various municipalities. Some municipalities have multiple triggers and see Laneway Housing as an aid in the achievement of desired housing goals such as increasing rental stock or attracting young couples in search of detached, single-family accommodations. Triggers can have greater impacts if there is proven community support behind it. For example, if a large portion of the population within a municipality is aging there may be a strong desire by residents to downsize from their current home given the fact they don't need as much space. The opportunities to build a home in their backyards allow them to age-in-place and still live in the same community. Therefore the trigger that sparked laneway housing policy was to provide residents with the opportunity to age-in-place. This may not typically not be a strong enough justification for such policy and often other triggers are included, however if there is significant community support, one particular trigger can be a key driver for Laneway Housing policy adoption.

\subsection{Technical Criteria}

Developing the criteria outlined in a Laneway Housing policy takes a considerable amount of time due to the research involved and data gathering specific to the particular municipality. One of the first areas examined are the geographic and environmental characteristics and the development pattern of the roads, lanes and servicing infrastructure networks throughout the jurisdiction. Some communities may have well-developed lane systems and small to moderate sized lots with relatively flat topography. Others may have more irregular shaped lots, few lanes and more challenging topography (Interview with Planner B, 2014). Both scenarios can have success with laneway housing development, however the regulations or criteria put in place may look different. For example, one municipality may have limited lanes but large lot sizes and may set a regulation that states properties 
over a certain square footage can also build a laneway house without being on a lane as a way to compensate for fewer lanes.

Servicing laneway houses has also posed as an obstacle for property owners due to the variable costs which are highly dependent on the location of existing service connections. However, from the point of view of an individual municipality, they would only inform property owners of where the municipal service points are for sanitary, storm and water and the cost to connect to these services and how to contact other service providers to determine if, hydro, or gas extensions are required and at what cost (City of Vancouver, 2013). It would then be ultimately up to the property owner to determine if service is both feasible and financially viable. Property requirements are only a small portion of the overall criteria section because other site qualifications or criteria must be considered. Typical policy considerations related to property requirements include consideration of:

- Whether Laneway Houses are permitted in all residential zones or specified zones.

- Existing servicing infrastructure and access to it from the laneway.

- Minimum lot frontage and area.

- Permitted on lots with lanes.

- Permitted on corner lots.

- Permitted on lots over X square feet with or without a lane.

Site selection criteria must be given considerable attention when formulating laneway housing policy due to the diverse housing goals each municipality may want to achieve. Typically a city must determine if the owner can build a laneway house and have a secondary suite resulting in $\mathrm{X}$ number of units on one parcel of land. If increasing density in single-family areas is a goal of the municipality then this is a justifiable regulation. Cities must also determine if single lots must work within the existing permitted density in their zone or will be allowed additional density to accommodate the laneway house. For example, if all properties in Residential Zone 1 are permitted a floor space ratio(FSR) of 0.6, only lots which have not built to the maximum 0.6FSR can construct a laneway house (provided they have enough space leftover to reach minimum laneway house size standards). Some municipalities do however allow increases in density where laneway houses are permitted. 
Another consideration for communities is whether or not to allow the subdivision of the laneway house from the principle dwelling, thus creating two separate parcels of land either of which can be sold separately. Determining if laneway houses can be sold separate from the principle dwelling or are only used as rental properties can drastically change the intent of the policy. Currently a majority of municipalities permit laneway housing as rental units only and subdivision of a single-family lot to sell a laneway house has not been utilized. The approach taken to stratification in these jurisdictions is to create a separate zone for this type of infill housing which may also exceed the typical 1,000 square foot size limit (Planner B, 2014).

Finally, municipalities must give thought to whether they will require the owner to live on the property for which a laneway house is constructed on. This is often related to the triggers of the policy such as keeping families in the jurisdiction (or encouraging the children of the owners and their families to return), ageing-in-place or because economic gain from laneway house construction is not the main goal of residents and the city. Considerations specific to each municipality include:

- Secondary suite and laneway house permitted on same parcel

- Increase allowable floor area for zones permitted to build a laneway house or keep it the same

- Strata-titled or rental use only

- Owner must live on property or not

\subsection{Design Guidelines}

Creating a robust, clear and visual set of design guidelines is an important aspect of successful laneway housing policies. It allows the developer to construct a unit that meets political and community approved regulations. By incorporating visual images (i.e. potential laneway housing layouts for one and two parking stall options) to explain the guidelines it ensures all requirements are met and easily understood by homeowners. Design guidelines will include setbacks from the lane, principle dwelling and side yards, maximum and minimum unit sizes to fit within the character existing houses, window placement to reduce overlook, maintaining existing trees on the property, landscaping features, fire access requirements, permitted height envelope, private outdoor space and parking requirements (City of Vancouver, 2013; City of North Vancouver Development Guidelines, 
2010). Again, these design guidelines will vary by municipality based on their physical characteristics. Cities with similar lots can implement fairly straight-forward guidelines which easily apply to a majority of eligible properties (See Figure A \& Figure B). However more complex property characteristics will require more detail. For example when laneway houses are permitted on larger lots without a lane, the design guidelines must illustrate solutions to setbacks, shared driveways, window placement, etc. These are often considered unique cases for a city and the more irregular or non-uniform the lot pattern is, the more complex the design guidelines and the approval process may need to be (See Figure C).

Another important consideration when developing guidelines is related to the nature or triggers of laneway housing in cities. For example, in the neighbourhood of East Clayton in Surrey, BC (See Figure D) laneway houses were built as part of a new subdivision with every home having a laneway house above a garage which fronted on a lane in hopes of adding sustainable density.

Additional density was achieved however the repressive uniformity of having a laneway house above the garage on every lot led to an unattractive, monotonous stretch of homes, much different than laneway house development in places like Vancouver where the new laneway house is added to the already existing main house (Planner B, 2014) (See Figure E). Laneway Houses are unique in character and design which is a large catalyst to their success in many Western Canadian municipalities. 

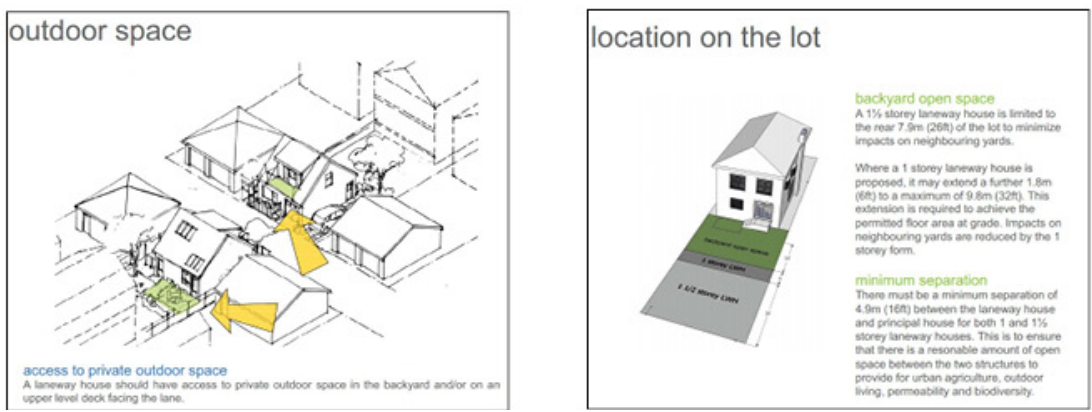

Figure A and Figure B: Vancouver, C. o. Laneway Housing How-to-Guide. Vancouver.

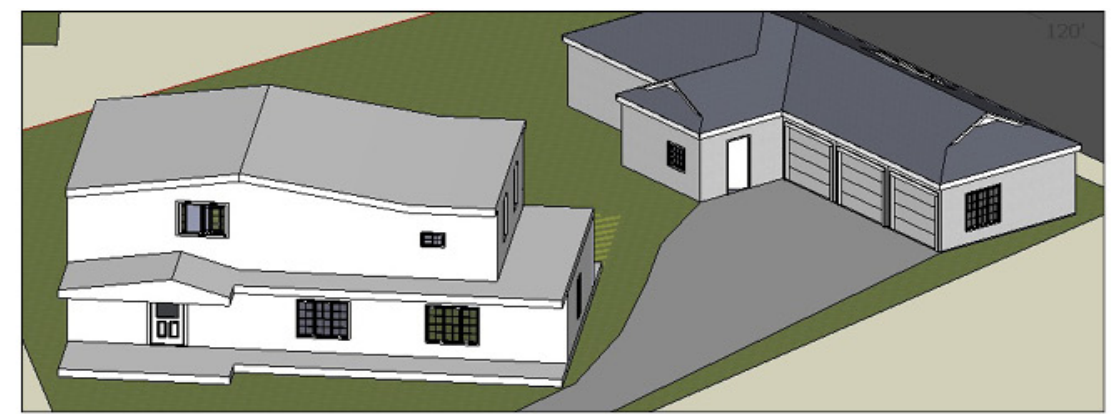

Figure C: Vancouver, D. o. Exploring Coach Houses in the DNV: A Discussion Paper. District of North Vancouver.

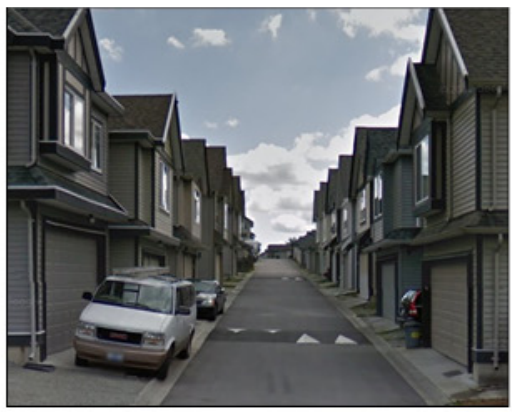

Figure D: Maps, G. East Clayton Coach Houses. Surrey.

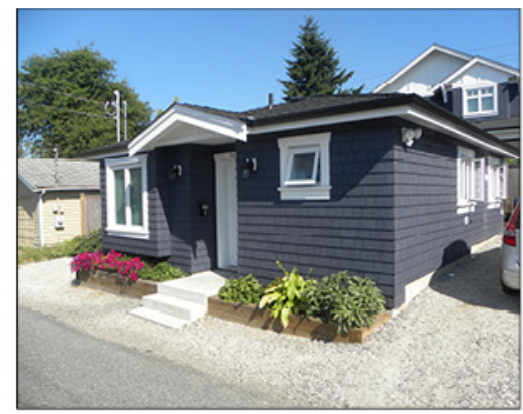

Figure E: Finley, B. Coach House in the CNV. City of North Vancouver.

\subsection{Approval Process}

The process by which laneway houses are approved is tailored to a municipality's goals, political climate and community acceptance. Legislative powers to approve Laneway Houses are derived from Provincial legislation including the Local Government Act in British Columbia and the Planning Act in Ontario although larger cities such as Toronto and Vancouver have their own Charters which gives them more powers than other cities and districts in their province. In the case of British Columbian municipalities (outside Vancouver) there are four paths or options that can be used to approve Laneway House applications. The selection of any of these depends on the 
uniqueness/goals of the policy and councils trust in staff to approve laneway houses that are in line with agreed upon criteria and guidelines. These options include approval by:

\section{Development Permit}

2. Development Variance Permit

\section{Individual/Spot Rezoning}

4. Amend Single Family Zoning By-Law to permit laneway houses

In order for a municipality to issue Development Permits in $\mathrm{BC}$ they must first establish a Development Permit Area. These areas can be created for certain purposes outlined in Section 919.1 of the Local Government Act and Laneway Housing has fallen under form and character for "Intensive Residential Development" in municipalities such as the City of North Vancouver (Planner A, 2014; CNV Official Community Plan, Schedule H Development Permit Areas, 2010). Development Permit Areas are often accompanied by a map that highlights affected properties as well as criteria for what requires a Development Permit. Municipalities then must decide whether Council or staff has the role of approving Development Permits for Laneway House development. For example, in the City of North Vancouver the Level-A Laneway House must be a maximum of 800 square feet and 1 storey/15 feet high. Council decided to delegate the approval of Level-A unit's role staff which required a bylaw to be passed (Planner A, 2014). It should be noted that if the approval process requires a Development Permit and the Laneway House proposal met all the zoning and design guideline requirements then Council/staff must issue the permit. This stems from a court case between Yearsly v. White Rock (City), 2009 in which Council's decision to deny a permit was overturned and deemed unlawful (Planner A, 2014).

Development Variance Permits allow a municipality to vary the siting and other development regulations such as height and setbacks within an existing zone. It does not permit changes to the use of the property or the density that is currently permitted. For example, if a Laneway House application proposed a two storey Laneway House within a zone that permits only one storey they would require a Development Variance Permit because it is above the allowable height however density cannot be increased. These permits are issued by Council and are often less costly and time consuming compared to other approval processes (Planner A, 2014). Currently the District of North Vancouver is proposing to redefine the term "secondary suite" so that the location of the suite may 
be varied on a single family lot. This scenario would also require a Development Variance permit even if they were one storey structures because the siting is being varied.

If a municipality intends to allow increased density on individual properties beyond what is currently permitted through the development of a Laneway House they can amend the Zoning Bylaw to allow the additional density or do individual/spot rezoning's (Planner A, 2014). Individual rezoning requires a bylaw to be introduced to Council for each lot with the desired changes, a formal Public Hearing before Council and eventual adoption or denial of the application by Council. This approach is very costly and often takes much more time than any other approval process (cost and time differ for each municipality). In any case it is likely that municipalities intending to increase permitted density in their Laneway Housing policy an amendment to their Zoning Bylaw will be required (Planner A, 2014).

A final option that would most likely see the largest increase in laneway house development would be to amend the Zoning By-law to permit laneway houses outright (or when a lot meets a strict set of criteria) and then the applicant would be required to apply for a Building Permit only. This policy option will yield a high number of applications and depending on the goal of the municipality could be a realistic option. The City of Vancouver's eco-density program wanted to increase density through laneway housing and therefore any size lot bigger than 33 feet wide in most single family zones could build one. Development Permits are still required however changes could come to the program if it is successful and Council desires a faster application process.

Determining who should approve laneway house applications is another debated topic among Councilors, Planners, Developers and the community. For a policy as new as Laneway Housing some communities may require Council approval even though it may result in fewer applications. This will allow Council to be perceived as directly responsive to the community as a whole and in cases where individual parcels are not uniform and irregular shaped, permit Council to interpret the guidelines themselves (Planner B, 2014). On the other hand, by having staff rather than Council, directly approve applications the process is streamlined, often less expensive and allows staff to work more directly with the applicant to ensure all criteria and guidelines are met. In either case, neighbourhood support must be demonstrated to ensure attempts are being made to reduce the impact on neighbours, however the extent to which this support must be proven varies with rezoning, development permits and development variance permits. 
Other aspects of the approval process include a pre-application review where a meeting is arranged with the planner and property owner to discuss and ensure all required documents are included in the formal submission. This is beneficial because Laneway Housing is a new policy and there is often confusion on the property owner's end as to what they need to produce. The application is then reviewed by city staff from relevant departments (Engineering, Fire Services, Environmental, etc.) in compliance with the adopted Laneway Housing design guidelines, revisions are made and the application is either approved or rejected (City of North Vancouver 2010; City of Vancouver, 2013).

In Ontario, the provision for Laneway Housing is not as established as many British Columbian municipalities. In 2011 the Strong Communities through Affordable Housing Act amended a number of sections within the Ontario Planning Act to facilitate the creation of second units through a number of requirements, most notably, "requiring municipalities to establish official plan policies and zoning by-law provisions allowing units in detached, semi-detached and row houses, as well as in ancillary structures" and defining second units as "self-contained residential units with kitchen and bathroom facilities within dwellings or within structures accessory to dwellings (such as above laneway garages)" (Ontario Ministry of Municipal Affairs and Housing, 2011). Laneway living is being recognized by the provincial government and the requirement for municipalities to create policies surrounding second units provides an opportunity to address laneway housing and formulate policy. Many of the approval processes would follow one of the four paths outlined earlier however the legislative power to approve these dwellings steams from different sections of the Ontario Planning Act. Ontario Regulation 608/09 s.15(1)(2)of the Ontario Planning Act allows municipalities to use, and gives power to Council and staff to approve, Development Permits. Section 45(3) provides Council with the power to grant authority to the Committee of Adjustment (appointed citizens that hold public hearings to consider minor variances) to approval minor variance applications.

\subsection{Community Engagement Strategy}

Once the technical criteria, design guidelines and approval processes have been researched and agreed upon by staff and Council, city staff will need to conduct community consultations on the proposed draft by-laws they have created. The goal is to gain feedback on the policy and explain various aspects to citizens who may be interested in building a Laneway House, opposed to them or 
curious as to their impact on their neighbourhood (Planner B, 2014). The strategy used by staff is unique and there is no perfect process however being able to ensure that the consultation process that is used garners sufficient feedback through various avenues of engagement is vital to the adoption of Laneway Housing policy. Public engagement strategies can include:

- Information displays

- Open Houses in central locations

- Online information

- Online/print questionnaires (key for gaining feedback)

- Social media to spread awareness of open houses and information

- Community venues/festivals

- Special presentations for community groups interested in information (ratepayers associations, etc.)

- Professional group working sessions for practical input (architects, designers)

Incorporating visual elements to explain the various design regulations outlined in the design guidelines is essential for community understanding. Once a community consultation process has been completed the results and feedback from questionnaires is analyzed, changes can be made to the draft by-law amendment or policy itself (depending on whether the municipality is seeking to rezone individual parcels, require development permits or development variance permits) and a report to council is formulated. 


\subsection{Methodology}

A mixed methods approach was adopted for this study which focused on in-depth interviews with professionals, quantitative policy analysis and research of various literature and print media. Interviewees were contacted initially through email and then by phone, all of which agreed to participate in in answering pre-determined questions. Each interviewee was selected because of their previous experience developing laneway housing policy and a snowballing technique was used to find other relevant participants during phone interviews. Each interviewee was a Planner from British Columbia and answered a series of questions which took approximately 20 minutes to answer with comments over the phone and through email being written down and transcribed. Overall four interviews were conducted focusing on questions that gained insight into what they believed to be key criteria/regulations paramount to successful laneway housing policy. The interviewees shared their opinions related to the reaction from the community and developers regarding their specific laneway housing programs. Other questions focused on ways their program could be improved and why they believe laneway living is a beneficial form of infill housing to their municipality. The interview guide can be found in Appendix B. Supportive analysis focused on each municipality's laneway housing policy that is currently adopted or in draft form. These documents clearly outlined key aspects of each municipality's goals and regulations related to laneway housing as well as provided additional information that could build on, and support, the knowledge gained through interviews. Finally, a few newspaper articles had congregated a number of key housing statistics related to laneway housing growth in a number of municipalities that were studied and this information was support through Statistics Canada. These were selected over other forms of media because they had strong sources, were the most up-to-date information available and were not biased as they were providing figures also offered by Statistics Canada. Key actors were identified through feedback from interviews and a literature review which commonly acknowledged who was involved in laneway policy development. The analyses of each policy will act as the basis for the case study and analysis portion of this paper through the development of comparative tables which allow for easy evaluation of each laneway housing policy. 


\subsection{Understanding Laneway Housing}

Through interviews, research of related laneway housing literature and several newspaper articles on the topic indicates that there are four groups of actors/stakeholders that are involved in the development of laneway housing policy (CMHC, 2009; Planner B, 2014; Planner C, 2014; Planner D, 2014). Each stakeholder has positive and negative attitudes about the impact of small infill housing on the built form of their communities, cities and regions. By examining the general outlook of Planners, Community Members, Developers/Property Owners and Councillors towards laneway house development municipalities who are contemplating, or currently have, policies can understanding each-other actors perspective and address common concerns throughout the community consultation and policy formulation process be achieved.

\section{The Planner}

Pros

o Makes single-family areas more efficient by increasing density and at times increasing use of underutilized servicing infrastructure.

o Increases rental stock and potentially opens up lower cost rental units as those that can afford newer laneway units move out of low-cost rental apartments

o Provides alternative form of housing outside of single-family and condominiums

o When done well laneway housing can add character to neighbourhoods and preserve current streetscape.

o Unique density solution to sprawling suburbs and has the potential to foster transit investment

Concerns

o Not the most sustainable way to add density (still sprawling out and not centering density).

o Should be a small portion of overall infill strategy, not main focus.

\section{The Community}

Pros

o Happy to have options, such as the ability to downsize and age-in-place, available to them.

o Multi-generational options (keep youth in area). 
O Prefer one storey over two stories.

o Affordable for middle-income earners to experience single-family living.

\section{Concerns}

o Construction occurring in small lot areas increases noise.

o Changes character of the neighbourhood

o Increases traffic

o Privacy/overlook from neighbours

o Not seen as being truly affordable housing.

\section{Developer/Property Owner}

Pros

o Provides separate unit to maintain privacy while allowing a source of income to supplement mortgage payment or pension income.

o Business opportunities for small home development companies.

o Opportunity to work closely with neighbour to ensure any issues are resolved early on.

\section{Concerns}

O Developers want increases in permitted density on site.

o Developers want intensity of accessory uses on sites by permitting secondary suites and laneway houses. This would allow more people to build a laneway house.

o Want more flexible guidelines to respond to more unique proposals rather than applying design standards collectively.

o Council should not be involved in deciding (Rezone/DVP). Slows down process, increases costs for property owner/developer.

o Less stringent parking requirements can increase affordability. Explore allowing laneway housing without parking around transit hubs.

\section{The Councillor}

Pros

o Increases property tax revenue.

o Can determine level of control through approval process. 
o Can aid in achievement of community defined and council approved goals outlined in Official Plans/Official Community Plans.

\section{Concerns}

o Community opposition may occur.

o Desire control over the approval of laneway houses which may lead to slower, more expensive process, potentially resulting in minimal uptake.

There a number of key takeaways that can be made from a brief analysis of the various actors and their attitudes towards the development of Laneway Houses in their municipalities. Firstly, there is a strong, collective understanding that developers desire an increase in the permitted density on a property looking to build a laneway house. This would allow them to sell the idea of a laneway house to property owners more easily and increase overall business. Developers also want secondary suites and laneway houses to be permitted on all parcels of land. This would significantly increase the number of developable properties and increase business.

From a Planner's perspective there a few concerns about the sustainability of laneway housing, being that it still follows the sprawl model, by not concentrating growth in a growth centre, however the benefits seem to outweigh the apprehensions. As long as it is only a portion of the infill strategy for a municipality, laneway housing achieves many desirable goals for a Planner including increasing rental stock, increasing housing options, attracting younger generations and allowing senior populations to age-in-place, among others.

From the community perspective, there is competing views regarding the attitudes the general public has towards laneway housing being permitted within their cities. Through interview discussions with Planners and community members, the general public is pleased to have additional options available to them and recognize that the benefits (option to downsize, stay in their community, keep family members close-by) outweigh the perceived drawbacks(Planner C, 2014; Planner D, 2014). They may not necessarily be interested in building a laneway house at the time the policy is adopted however knowing they have the opportunity to construct one on their property is a welcome benefit.

Finally, from Council's perspective they still desire some form of control over the approval of laneway house applications because it is a new policy. This goes against the ideology of property owner/developers who believe their time and money are being wasted because of the longer process 
Council sometimes desires. This step can be mitigated once the policy is in place for some time as we have seen in Vancouver and the City of North Vancouver with their two-tiered system whereby staff approves one storey units and Council approves any proposal over one storey.

\subsection{Laneway Housing in British Columbia: Indicators for Success}

The purpose of this section is to methodically break-down four different municipal laneway housing programs and review them against four laneway housing Principles. These principles include compatibility with neighbours, livability, suitability/effectiveness and administrative process, each of which are considerations for municipalities interested in laneway housing policy. The analysis will focus on why the four municipalities were selected and in general terms describe the four laneway Housing Principles that were developed and their relation to each municipality. Laneway housing policies will then be broken down into comparative tables in order to evaluate and analysis the differences in each municipalities program with respect to the evaluative criteria.

The first step involved identifying a number of cities that currently have laneway housing policy in place or are in the process of researching the possibility of formulating a policy. This provides a sample of jurisdictions at different stages of their policy development and a full picture as to how laneway housing programs have adapted overtime. The next step involved analyzing each laneway housing program in detail by developing a set of comparative tables that outlined common indicators of each municipality's laneway housing policy. Once the tables were formulated a set of laneway housing principles were developed to measure each municipality's laneway housing policy. Through discussions with Planners who have worked on laneway housing development in each municipality and analysis of various laneway housing guidelines it became evident that there were four main principles that embodied a strong laneway program. These were defined based on discussion with professionals and their definitions included a number of the indicators used within the comparative tables. Once the municipalities were selected, the laneway programs had been compared and the indicators were defined an analysis of each principle was undertaken that focused on whether the municipalities laneway housing program was strong, acceptable or could improve based on the principles definition.

The four cities that were selected include the City of Vancouver, the City of North Vancouver (CNV), the District of North Vancouver (DNV) and the District of West Vancouver (WV). The City of Vancouver was analyzed because they have taken a lead role in laneway house 
development in Canada over the past five years with this type of development steadily increasing and City Council adapting to user and community feedback. Their experience reviewing a high number of applications (approximately 1,300) can provide insight into success points and potential areas of concern in policy formulation (Planner C, 2014).

The City of North Vancouver was selected because their program is relatively new, having only been adopted in 2010 . They have also found success with their program and developed creative solutions to address neighbourhood impact by splitting coach house development into Level-A and Level-B applications based on unit size and height.

The District of North Vancouver was selected for two key reasons. The first is that they are currently at the very beginning of their policy formulation process having recently developed a discussion paper approved by Council. Staff has been directed to gain community feedback on the proposed criteria. The second reason is the physical makeup of their jurisdiction which consists of limited laneways, much larger lots and challenging topography (located mainly on a mountain) when compared to the other two municipalities. Examining the innovative solutions they have developed to thwart these challenges not only provides solutions to other municipalities with similar physical characteristics, but shows that there are ways to overcome geographic and environmental issues if community support exists.

Lastly, the District of West Vancouver was selected because they are one step ahead of the District of North Vancouver and currently in the middle of community consultations. They have created some unique criteria that addresses geographical context, similar to the District of North Vancouver but with a different approval process proposed. 


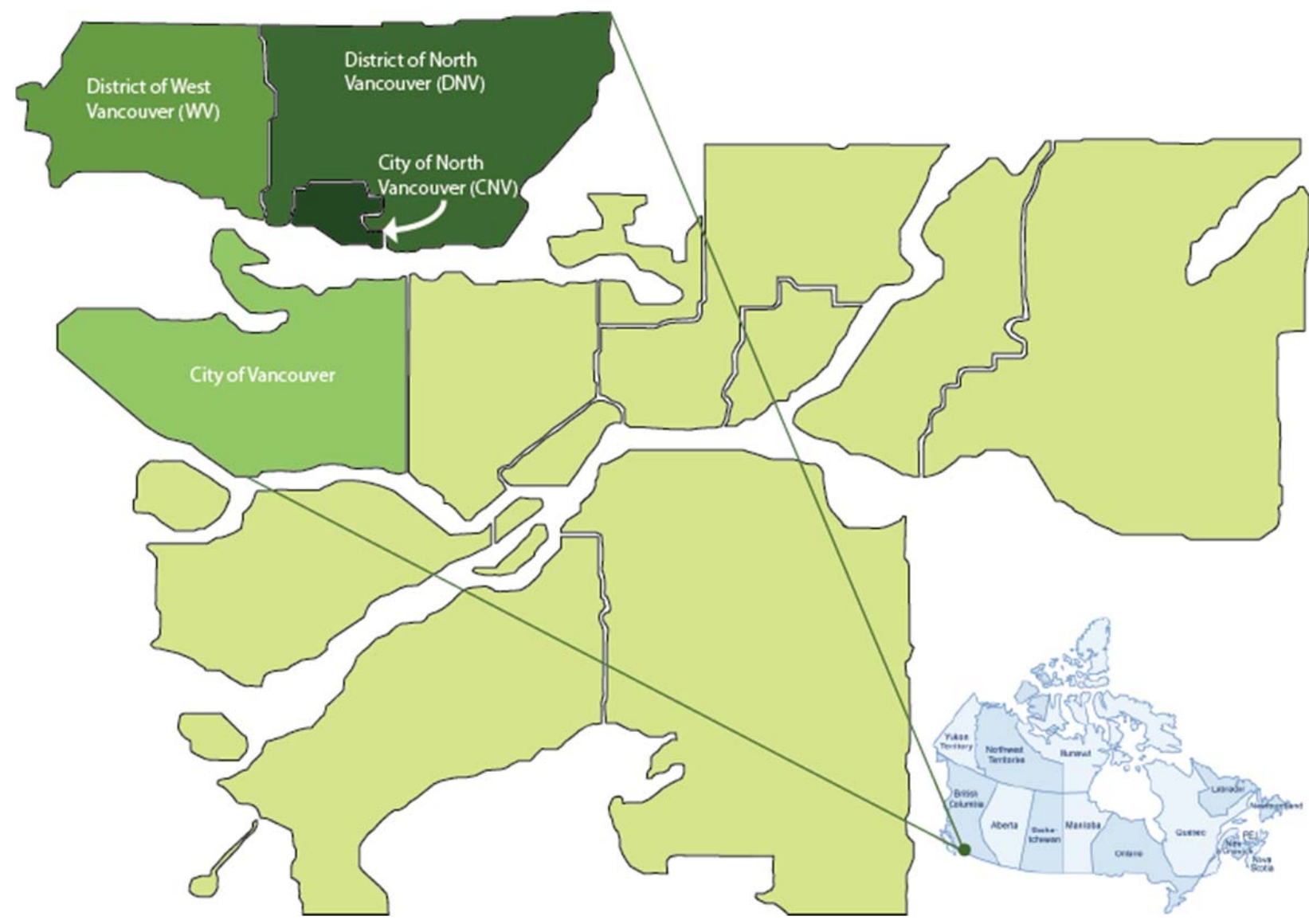

Figure F: Ltd., F. H. Map of Canada. And Out, K. Map of Metro Vancouver.

\section{Compatibility with Neighbours}

In order to develop a successful laneway housing program, municipalities must consider the potential impacts laneway homes will have on neighbours. For the purpose of this analysis, compatibility with neighbours relates to ensuring the laneway policy has measures in place to minimize changes to the streetscape (including lanes) by enhancing the area with landscaping, maintains the privacy of adjacent properties by reducing overlook through window placement, deck orientation and attempts to promote 1 storey units over 2 storey units. Other indicators include requirement for sufficient parking to be provided on-site to minimize on-street congestion, the promotion of neighbour consultation to make neighbours aware of the development and appropriate limits to the size of laneway houses on individual parcels of land to reduce building bulk. Lastly, the minimum lot frontage requirements need to be compatible with the municipality and limit the impact a laneway house has on a neighbouring property. In some cases (particularly with 33 foot wide lots) it may be unrealistic to build a laneway house under the existing density allowance as there 
is often no additional density leftover over once the principle dwelling is built. Therefore, in municipalities with many small lot frontages a density boost is the only way to ensure laneway housing is compatible for that area.

\section{Liveability}

The prospect of living on a lane is relatively new and there are obvious apprehensions when it comes to this form of living. Laneway homes are also a much smaller form of single-family housing and therefore questions often arise surrounding their ability to provide enough space for prospective tenants while still fitting into the existing neighbourhood character. Therefore, municipalities must build into their laneway housing programs aspects that enhance overall livability and ensure regulations are in place that will provide sufficient space to maintain or increase one's quality of life. There are several policy aspects that can be analyzed to determine how well municipalities are doing in promoting livability through laneway housing including the minimum size of laneway homes to ensure they are large enough, separation requirements between the principle dwelling and the laneway house to ensure there is enough backyard space for both units, the impact of parking requirements and how they can force floor space to the second floor and finally landscaping obligations. Other indicators include whether or not outdoor balcony or deck space is allowed, if there are exemptions in the permitted density on the site for storage space and the promotion of 1 storey laneway houses to enhance accessibility which is an important factor for dwellings targeted towards ageing-in-place triggers.

\section{Suitability and Effectiveness}

Determining if a laneway housing program is effective relates to two key questions- "What is the municipality aiming to achieve from this policy?" and "What regulations are in place that will help them achieve this outcome?" There is some overlap with the suitability of the program as some regulations are more suitable to particular municipalities given their laneway housing goals. For example, Vancouver's laneway housing policy was driven by an initiative called Eco-Density and the aim was to increase the overall density in single-family neighbourhoods in a sustainable way through laneway housing. Therefore it would be expected that laneway houses are permitted widely across the municipality. A similar provision may not be suitable for other municipalities with different housing goals. Therefore effectiveness, for the purposes of this analysis, relate to the type of laneway housing guidelines put in place to help achieve the desired goals of the program. This can include 
the provision to allow both secondary suites and laneway houses, requiring the owner to reside on the property, whether the policy is part of the Official Community Plan or Housing Action Plan and the overall number of laneway houses currently built. However, this evaluation must keep in mind the original intention of the laneway housing policy in order to accurately assess the success of the program. For example, just because a program restricts the owner to having either a LWH or a secondary suite but not both does not mean that the program in the context of that specific municipality is ineffective.

Suitability, on the other hand, relates to two key factors; the overall neighbourhood reaction to the idea of permitting laneway house construction and examining the geographical breakdown of the municipality in relation to topography, the pattern of development and the pattern of subdivision. It is much easier to find success with laneway housing when the municipality is relatively flat, has a grid system with lanes and similar lot sizes as opposed to a mountainous topography with curvilinear development patterns and irregular lot sizes. Examining criteria such as the requirement to reside on a lane, minimum lot frontage requirements and how a municipality tailors their laneway housing policy to the geographical make-up of their jurisdiction will be analyzed across all four municipalities. Lastly, municipalities must decide on the type of situation laneway housing will be permitted for. For example is laneway housing for infill situations, allowed only when lot is being totally re-designed or just for new Greenfield developments. These all have different impacts on the built form of a municipality and some may not find the outcomes suitable to their goals.

\section{Administrative Process}

There are several laws municipalities must adhere to when issuing a development permit, development variance permit or rezoning a property to allow a laneway house to be built. In a general sense the planning process that each municipality follows should be fair, equitable and consistently applied across the jurisdiction. In Ontario, section 1.1(d) of the Planning Act states that planning processes should be fair by making them open, accessible, timely and efficient. In British Columbia the planning and land-use provisions outlined in the Local Government Act provide authority to local governments to make responsive planning decisions that balance the needs of affected parties. Also section 1.4 of the Canadian Institute of Professional Planners Code of Professional Conduct (2014) requires Planner's to “provide opportunities for meaningful 
participation and education in the planning process to all interested parties." There are two separate times to evaluate how well administered, responsive and successful laneway housing policy is within a given jurisdiction. The first time is when the policy is being developed and the community engagement strategies used by each municipality. This is more related to the suitability of the policy. The second time is after the adoption of the policy and how open the approval process is and how if the municipality is making changes to the policy in response to neighbourhood feedback. By examining the neighbourhood notification process (formal notification sent to neighbours to inform them who is building a laneway house) and who has approval authority can help define how equitable the process is for each municipality. Furthermore examining the overall time and municipal fees charged to process a laneway house application can have an impact of the uptake of laneway house construction. For example, if fees and processing time are high and the outcome uncertain then it would be assumed that few property owners would apply to build. By comparing each municipalities average costs and timelines it will become evident what processes are the fastest and cheapest for the property owners and which municipalities make more conducive for their residents to build a laneway house. 


\subsection{Indicators/Key Factors Summarized}

\begin{tabular}{|l|}
\hline \multicolumn{1}{|c|}{ Compatibility with Neighbours } \\
\hline Minimize changes to streetscape \\
\hline Reduce overlook and promote 1 storey over \\
2 storey \\
\hline Parking requirements \\
\hline Neighbour consultation \\
\hline Maximum laneway house size \\
\hline $\begin{array}{l}\text { Minimum lot frontage and permitted on-site } \\
\text { density }\end{array}$ \\
\hline
\end{tabular}

Table 2: Indicators for Compatibility with Neighbours

\begin{tabular}{|l|}
\hline Suitability \\
\hline Community Acceptance of laneway housing \\
\hline Topography \\
\hline Pattern of Development \\
\hline Pattern of Subdivision \\
\hline $\begin{array}{l}\text { Permitted for certain redevelopment } \\
\text { situations }\end{array}$ \\
\hline
\end{tabular}

Table 4: Indicators for Suitability

\begin{tabular}{|l|}
\hline \multicolumn{1}{|c|}{ Livability } \\
\hline Minimum laneway house size \\
\hline $\begin{array}{l}\text { Separation between principle dwelling and } \\
\text { laneway house }\end{array}$ \\
\hline Parking requirements \\
\hline Landscaping regulations \\
\hline Providing outdoor deck space \\
\hline FSR exemptions for storage \\
\hline
\end{tabular}

Table 3: Indicators for Livability

\section{Effectiveness}

Vancouver $=$ Promote density

$\mathrm{CNV}=$ Increase rental stock and diversify

housing types

DNV = Allow for ageing-in-place, keep families in the neighbourhood, diversify housing types

$\mathrm{WV}=$ Diversify housing types, provide options to downsize (age-in-place).

Uptake numbers to determine if laneway housing policy is effective

Table 5: Indicators for Effectiveness

\section{Administrative Process}

Notification process

Approval authority

Total processing costs

Total processing time

Table 6: Indicators for Administrative Process

\subsection{Comparative Tables}

Each municipality's laneway housing policy has been broken down through this study into comparative tables which address many of the principles and indicators previously discussed. These tables allow for in-depth analysis and discussion around each municipality's program and whether or 
not they are strong, acceptable or weak in particular areas. For example, in order to determine if the District of North Vancouver has a strong administrative process in relation to laneway housing it would be assumed that the notification process covers a large area, time and costs are reduced and uptake numbers are high (or in the DNV's case, expected to be high). 


\begin{tabular}{|c|c|c|c|c|c|}
\hline & \multicolumn{5}{|c|}{ Criteria/Site Qualification } \\
\hline & $\begin{array}{l}\text { District of } \\
\text { North } \\
\text { Vancouver }\end{array}$ & \begin{tabular}{|l} 
City of North \\
Vancouver Level A
\end{tabular} & $\begin{array}{l}\text { City of North } \\
\text { Vancouver Level B }\end{array}$ & Vancouver & West Vancouver \\
\hline $\begin{array}{l}\text { Minimum Lot } \\
\text { Frontage }\end{array}$ & $50 \mathrm{ft}$. & $33 \mathrm{ft}$. & $33 \mathrm{ft}$. & $\begin{array}{l}32.15 \mathrm{ft} \text {. (Can be } \\
\text { approved on } 24 \mathrm{ft} \text {. lots } \\
\text { if neighbour impact is } \\
\text { minimal) }\end{array}$ & $50 \mathrm{ft}$. \\
\hline $\begin{array}{l}\text { Minimum Lot } \\
\text { Area }\end{array}$ & TBD & 3,900 sq. ft. & 3,900 sq. ft. & Depends on RS Zone & None \\
\hline $\begin{array}{l}\text { Maximum Site } \\
\text { Density }\end{array}$ & $\begin{array}{l}\text { Maintain } \\
\text { maximum FSR } \\
(0.35 \mathrm{x} \text { lot area } \\
+350 \text { sq. ft. })\end{array}$ & $\begin{array}{l}\text { Maintain maximum } \\
\text { FSR }(0.5 \times \text { lot area } \\
\text { OR } 0.3 \times \text { lot area }+ \\
1,000 \text { sq.ft. (which } \\
\text { ever is less) }\end{array}$ & $\begin{array}{l}\text { Maintain maximum } \\
\text { FSR }(0.5 \times \text { lot area } \\
\text { OR } 0.3 \times \text { lot area }+ \\
1,000 \text { sq.ft. (which } \\
\text { ever is less) }\end{array}$ & $\begin{array}{l}\text { Regardless of current } \\
\text { density on site a } \\
\text { Laneway House can be } \\
\text { built (following max. } \\
\text { LWH Floor Area) }\end{array}$ & $\begin{array}{l}\text { Maintain existing } \\
\text { FSR per existing } \\
\text { zoning (Properties } \\
\text { built to max. FSR } \\
\text { would not be } \\
\text { eligible) } \\
\end{array}$ \\
\hline $\begin{array}{l}\text { Minimum } \\
\text { Laneway } \\
\text { House Floor } \\
\text { Area }\end{array}$ & TBD & Not Specified & Not Specified & 280 sq.ft. & 400 sq.ft. \\
\hline $\begin{array}{c}\text { Maximum } \\
\text { Laneway } \\
\text { House Floor } \\
\text { Area }\end{array}$ & $\begin{array}{l}\text { The lesser of } \\
\text { available } \\
\text { unrealized density } \\
\text { ot } 968 \text { sq. ft. } \\
\text { (Same as } \\
\text { Secondary Suites) }\end{array}$ & $\begin{array}{l}\text { The lesser of } 0.15 \mathrm{x} \\
\text { lot area OR } 800 \\
\text { sq.ft. }\end{array}$ & $\begin{array}{l}\text { The lesser of } 0.15 \mathrm{x} \\
\text { lot area OR } 1,000 \\
\text { sq. ft. }\end{array}$ & $\begin{array}{l}\text { Maximum is } 900 \text { sq. } \\
\mathrm{ft} \text { on } 50^{\prime} \text { x } 122^{\prime} \\
\text { AND } 644 \text { sq. ft. on } \\
33^{\prime} \text { x } 122^{\prime} \text { ( }+ \text { a } 40 \text { sq. } \\
\text { ft. storage exclusion) }\end{array}$ & $\begin{array}{l}0.1 \mathrm{x} \text { lot area to a } \\
\text { maximum of } 1,200 \\
\text { sq.ft. }\end{array}$ \\
\hline $\begin{array}{l}\text { Zone/Permitted } \\
\text { Uses }\end{array}$ & $\begin{array}{l}\text { All RS zones on a } \\
\text { site-by-site basis }\end{array}$ & All RS Zones & All RS Zones & $\begin{array}{l}\text { All RS single family } \\
\text { zones }\end{array}$ & $\begin{array}{l}\text { RS1-RS10, RD1, } \\
\text { RD2 and RD6 }\end{array}$ \\
\hline Lane Access & $\begin{array}{l}\text { Required (unless } \\
\text { corner lot or over } \\
10,000 \text { sq. ft.) }\end{array}$ & Not Required & Not Required & $\begin{array}{l}\text { Required (unless corner } \\
\text { lot or double fronting } \\
\text { on two streets) }\end{array}$ & Not Required \\
\hline $\begin{array}{l}\text { Permitted on } \\
\text { corner }\end{array}$ & Yes & Yes & Yes & Yes & Yes \\
\hline $\begin{array}{l}\text { Secondary } \\
\text { Suite permitted } \\
\text { with LWH }\end{array}$ & No & No & No & Yes & No \\
\hline $\begin{array}{l}\text { Rental or Strata- } \\
\text { titled }\end{array}$ & Rental & Rental & Rental & $\begin{array}{l}\text { Rental (Strata-titled } \\
\text { only if Historic } \\
\text { Designation) } \\
\end{array}$ & Rental \\
\hline $\begin{array}{l}\text { Owner } \\
\text { Occupancy } \\
\text { Required } \\
\end{array}$ & Yes & Yes & Yes & No & Yes \\
\hline
\end{tabular}

Table 7: Summary of Laneway Housing Criteria 
Design Considerations

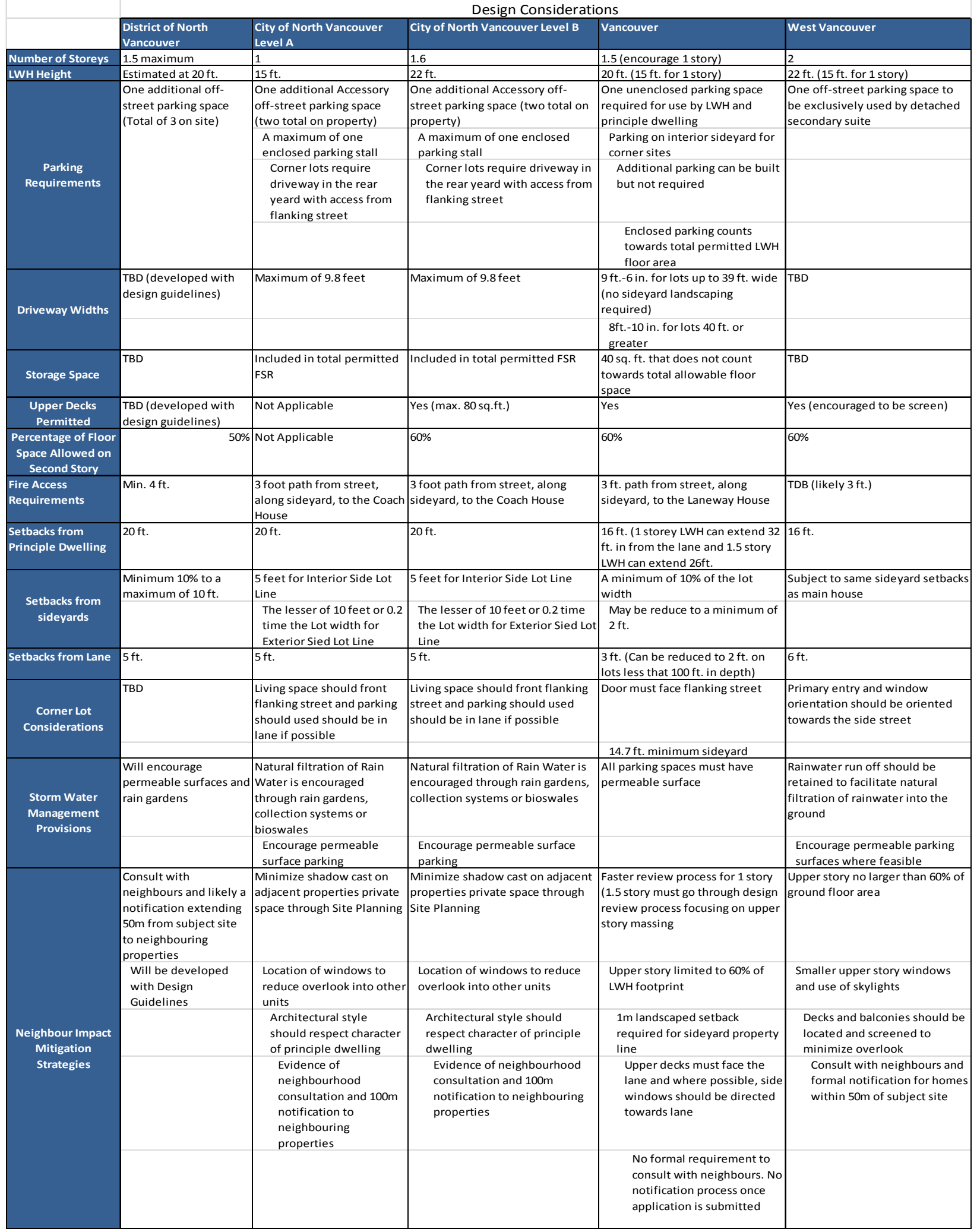

Table 8: Summary of Laneway Housing Design Guidelines 
Administrative Process

\begin{tabular}{|c|c|c|c|c|c|}
\hline & $\begin{array}{l}\text { District of North } \\
\text { Vancouver* } \\
\end{array}$ & $\begin{array}{l}\text { City of North } \\
\text { Vancouver Level A } \\
\end{array}$ & \begin{tabular}{|l} 
City of North \\
Vancouver Level B \\
\end{tabular} & Vancouver & West Vancouver* \\
\hline $\begin{array}{l}\text { Provincial Legislation } \\
\text { Provisions }\end{array}$ & Local Government Act & Local Government Act & Local Government Act & Vancouver Charter & Local Government Act \\
\hline $\begin{array}{l}\text { Can Require } \\
\text { Development Variance } \\
\text { Permit }\end{array}$ & Yes & No & Yes & No & No \\
\hline $\begin{array}{l}\text { Can Require Individual } \\
\text { Rezoning }\end{array}$ & No & No & Yes & No & Possbile \\
\hline $\begin{array}{l}\text { Can Require } \\
\text { Development Permit }\end{array}$ & No & Yes & No & Yes & Yes \\
\hline Approval Authority & $\begin{array}{l}\text { Council to begin } \\
\text { approving all } \\
\text { applications and then } \\
\text { review policy after 2-3 } \\
\text { for possible staff } \\
\text { delegation }\end{array}$ & Staff & Council & Staff & Staff \\
\hline Notification Area & $\begin{array}{l}\text { Adjacent properties } \\
\text { and } 3 \text { in front and } 3 \text { at } \\
\text { the back/rear }\end{array}$ & $100 \mathrm{~m}$ & $100 \mathrm{~m}$ & None & $50 \mathrm{~m}$ \\
\hline $\begin{array}{l}\text { Total Process Costs to } \\
\text { LWH Builder }\end{array}$ & $\begin{array}{l}\$ 900 \text { for DVP plus } \\
\text { Building Permit } \\
\end{array}$ & $\$ 500$ just for DP & $\$ 1,750$ for rezoning & $\begin{array}{l}\$ 1,000 \text { for } 1 \text { story, } \\
\$ 1,520 \text { for two story }\end{array}$ & Unknown at this point \\
\hline $\begin{array}{l}\text { Total Time to Process } \\
\text { Application }\end{array}$ & Approx. 13-16 weeks & $\begin{array}{l}\text { Approx. } 4 \text { months } \\
\text { with Building Permit }\end{array}$ & $\begin{array}{l}\text { Approx. 6-8 months } \\
\text { with Building Permit }\end{array}$ & 3-4 months & Unknown at this point \\
\hline Current Uptake Numbers & 0 & 14 & 13 & $\begin{array}{l}\text { Approx. } 1,300 \\
\text { permits issued }\end{array}$ & 0 \\
\hline
\end{tabular}

*Policy may change with community feedback

Table 8: Summary of Laneway Housing Administrative Processes 


\subsection{Analysis and Discussion}

There are many policy areas in which all municipalities provide acceptable regulations that address the indicators listed. For example, design guidelines for all jurisdictions state that windows and upper decks/balconies should be oriented towards the lane to reduce overlook into adjacent backyards and that upper storey massing should be kept to a maximum of $60 \%$ of the ground floor for similar reasons (District of North Vancouver likely to impose the same regulation). The analysis of these policies will focus on where municipalities have achieved success with specific indicators and where they could potential encounter issues related to compatibility with neighbours, overall livability, the effectiveness of laneway housing at reaching desired housing goals and the administrative process.

\section{Compatibility with Neighbours}

The first of six indicators that relate to how well a laneway housing policy considers neighbour impacts is its ability to minimize changes to the streetscape. All four municipalities strongly encourage enhancements to the laneway but very few require landscaping to occur as the guidelines are meant to be somewhat flexible to adhere to unique design situations. Vancouver has the strongest landscape guidelines as they require some form of side-yard hedge/shrubbery next to Figure G: Vancouver, C. o. Laneway Housing How-to-Guide.
Vancouver.

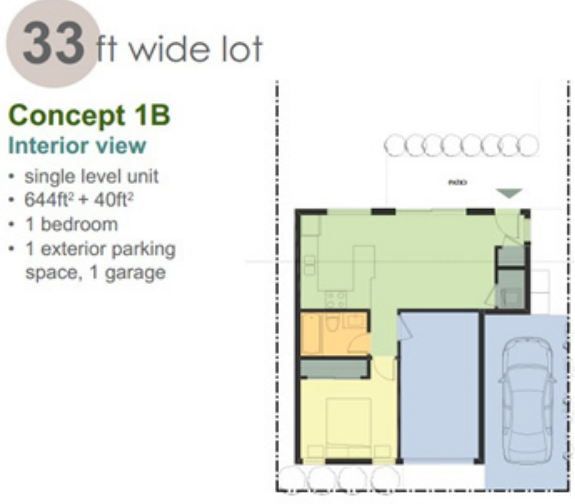

\section{$50 \mathrm{ft}$ wide lot}

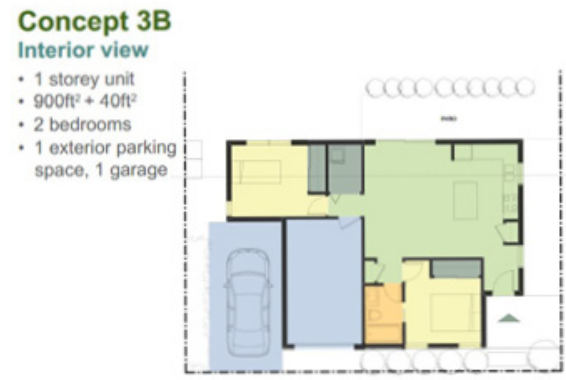

the unenclosed parking space, the amount of which changes with the width of the lot. They also provide an extensive list of drought-tolerant plants and lighting options to not only minimize changes to the streetscape but enhance it.

The ability to reduce overlook into neighbouring properties is an important piece of each municipality's guidelines as this is a common criticism of laneway housing. Each community has numerous steps in place to reduce this from occurring through distinctive design solutions. The City of North Vancouver, for example, typically promotes bedrooms in the upper floors and not living space to reduce the time spent on 
the second floor. They have also developed a two-tier approach with Level -A coach houses (one storey) only requiring a Development Permit (faster and less expensive p rocess) and Level-B coach houses requiring a Rezoning or Development Variance Permit (longer and more expensive). This issue has become so large in Vancouver that when they conducted their policy review after the first 500 laneway house applications, changes were made to promote one storey over two storey units. One storey units can now extend into the rear yard an additional 6 feet so all floor space can be on the ground floor (kept the 16ft separation from the principle dwelling) and created a faster review process for 1 storey applications (1.5 storey units must go through a design review focusing on upper storey massing). These changes have increased one storey applications from $6 \%$ to $14 \%$. Since the City of North Vancouver is the only other municipality studied that has 33 foot wide lots, they may consider a similar approach if neighbours feel 1.5 storey units are too overbearing for that wide of a lot.

When analyzing neighbour compatibility, parking regulations are strictly focused on reducing on-street parking. Other contradictory issues due arise with parking requirements and the effect on livability however he focus of this portion of the analysis is related to the reduction of on-street parking. Vancouver requires one space be provided for use by the main dwelling and laneway house (and potentially secondary suite) resulting in a large amount on on-street parking in single-family residential areas. The City of North Vancouver and West Vancouver require one space for the main house and one space for the laneway house whereas the District of North Vancouver requires two spaces for the main house and one for the laneway house or attached secondary suite. Therefore in terms of neighbour compatibility the DNV provides the most parking and Vancouver provides the least however on-street parking is common practice in Vancouver and few complaints are made to the City regarding increased parking when laneway house applications are brought forward (Planner D, 2014). They have also provided images on their website showing how two parking spaces can work on various shaped lots. (See Figure G). Large amounts of on-site parking may be ideal for reducing on-street parking however the impacts on unit livability may be more significant.

Neighbours need to be informed about laneway development as the potential design could potentially impact their property and additional noise from construction and use of laneway homes could have an effect on their day-to-day lives. Therefore the West Vancouver, the City and District of North Vancouver require proof that some form of neighbourhood consultation took place prior to submitting a formal application to inform neighbours of your development. They also have a 
formal notification process that range from 100 meters for the City of North Vancouver, 50 meters for the District of North Vancouver, and 50 meters West Vancouver. The CNV has actual found that because the homeowners are the applicants, they are worried about the reactions of their neighbours (often friends) and will seek them out unbeknown of the requirement in place by the City to do so (Planner C, 2014). Vancouver however has no formal requirement to inform neighbours of the development and no notifications are sent with the Development Permit. This can result in heightened levels of neighbour complaints and push-back to laneway housing development in some neighbourhoods.

Ensuring the maximum laneway house size is relative to the size of the lot is imperative to ensure the bulk of the laneway house does not drastically change the neighbourhood character and infringe on neighbouring properties. All municipalities, other than the District of North Vancouver, take lot size into consideration when determining how large a laneway house can be built. For example, West Vancouver's maximum size is 0.1 times the lot size to a maximum of 1,200 square feet. The DNV currently has the maximum size set to similar standards as secondary suites (968 square feet) provided the lot has that amount of unrealized floor space. It should be noted that WV's current proposal of 1,200 maximum square feet is much larger than any other municipality and has a much higher probability of disrupting neighbourhood character and creating a sense of overbearing on neighbouring properties. However, since that municipality has extremely large homes and many estate sized properties (e.g. over 20,000 square feet), it may be relative when compared to Vancouver who which has many smaller laneway houses with smaller principle dwellings on much smaller properties (e.g. 4,000 square feet). As well, the 1,200 square foot limit is a maximum size and it does not have to be approved if deemed incompatible for a smaller lot in that municipality.

Finally, minimum lot frontages and permitted on-site density can be important policy tools used to shape laneway house programs to ensure they are compatible to a neighbourhood. For example, laneway housing on 33 foot wide lots is not seen as compatible, or possible, if no additional density is permitted on the site. There are very few cases where a 33 foot wide lot has additional density leftover to build a livable laneway house, and if there is a property that does then the construction of that laneway house on one property in a neighbourhood is likely to change the character of the area. Vancouver recognized this and provided all properties with an additional 0.16 FSR on all residential lots to promote laneway house construction and ensure everyone else in 
neighbourhoods with 33 foot lot frontages had the opportunity to build a laneway house.

Municipalities such as the District of North Vancouver and West Vancouver have minimum lot frontages of 50 feet and very few 33 foot wide lots and therefore are able to not provide additional density for the construction of laneway houses as many properties are likely to have leftover density. If both these jurisdictions find minimal uptake occurring due to properties not having enough leftover density (this could be possible due to the high number of large homes in both Districts), additional density could be a solution if either municipality wanted to change the primary focus of these programs. Finally, the City of North Vancouver is unique as their minimum lot frontage is 33 feet however no additional density is being provided. There is minimal information regarding the uptake of laneway housing on 33 foot lots in the CNV however if issues arise, a boost in density may make this form of housing more compatible in specific neighbourhoods.

\section{Livability of Laneway Housing}

A minimum standard laneway house size is often set for municipalities to ensure laneway homes are being constructed to a size that can produce enough livable space. West Vancouver and Vancouver were the only jurisdictions that indicated a minimum size with 400 square feet and 280 square feet limits respectively. Limited data exists on the amount of laneway homes being constructed at 280 square feet however it is an extremely small amount of living space for a singlefamily area when studio apartments average 350-450 square feet and many one bedrooms are in the 475 - 525 square foot range in condominiums. The City of North Vancouver and District of North Vancouver do not have minimum lot sizes stated and may need to consider setting a standard as some properties with limited leftover density may try to build units not in-line with the municipality's vision (very small units). Overall it is good to have a minimum standard, however 280 square feet is too low and should be brought up to 400 to ensure livability is achieved. Studio size units are inconsistent with the prevalent size of secondary suites in places like the DNV and would likely to be too small to achieve their goal of laneway housing which is to allow family oriented occupancy.

A strong indicator of livability is also the space required between the principal dwelling and the laneway house. The greater the separation, the greater the opportunity to provide private outdoor space which make the unit more livable for potential tenants and retains liveability for the principle dwelling. West Vancouver and Vancouver have a minimum separation of 16 feet whereas 
the CNV and DNV require a 20 foot separation. 16 feet seems standard for a municipality like Vancouver who has smaller lots and may need to decrease the space to allow laneway houses to be constructed however it does not seem to make sense for WV. With large lots this number could be pushed to 20 feet to offer more opportunity for developing livable space. An interesting note is that less separation between units allows for more upper storey space to fit on the ground floor, providing easier one storey laneway house development and making them more accessible (a benefit for ageing-in-place).

As mentioned previously, evaluating parking requirements is essential to ensure laneway housing programs are compatible with neighbours and to reduce on-street parking demand. However, Vancouver experienced issues with their previous policy in which enclosed parking space was being used as living space and thus, no off-street parking was being provided for any of the three possible units. Recent changes to the program now require one unenclosed parking space. This could be an indicator that laneway house sizes are currently too small in Vancouver and there is a market for larger units even with the density bonus. The District of North Vancouver has the opposite approach in which they require three parking spaces to be provided and all three can be enclosed. Issues will likely arise with this garage space counting in the floor space, being turned into living space and adding to the bulk of the new laneway or coach house. Therefore larger units could be an option for the District of North Vancouver similar to West Vancouver's maximum unit size of 1,200 square feet and two parking spaces (one or both being unenclosed) at some point in the future.

Landscaping enhances livability for both the tenants of laneway houses and the owners of the main household. As mentioned previously, Vancouver has very strong landscaping regulations with many laneway houses providing landscaped setbacks from the lane, requiring permeable parking surfaces and tree retention. The City of North Vancouver promotes these as well, however no regulations are in place to ensure landscaping occurs to produce more livable spaces. The District of North Vancouver and West Vancouver have preliminary objectives to ensure landscaping transpires with laneway homes however these will be more defined once community consultations take place.

Second floor deck/balcony space is often used as outdoor private space and Vancouver will allow a deck to be constructed in lieu of providing ground-floor private space. All municipalities 
allow a deck to be constructed which makes the laneway house more livable for the owner/tenant. However this can also have a negative impact on the neighbour due to increased possibilities of overlook. It is obvious all jurisdictions see the benefits deck space can bring and have developed design guidelines to minimize infringement on neighbours as a way to mediate the matter. Decks and balconies must always be included in any evaluation of the impact on a neighbourhood when they are being designed as living space (Planner B, 2014).

Finally, in an effort to make laneway homes more livable the City of Vancouver has changed their program to allow a 40 square foot exemption from the permitted total density to allow for the construction of storage space. This space can be used for bike storage, crawl space or garbage and recycling. The idea is that owners will not have to use their own density to build something Vancouver considers necessary for every home. All three other municipalities do not currently do this however the City of North Vancouver could justify a similar exemption for one storey units who currently have a maximum size of 800 square feet whereas West Vancouver will likely not be able to justify an exemption as their maximum unit size is 1,200 square feet. The District of North Vancouver may also consider providing an exemption in FSR for storage space as their current maximum laneway size is 968 square feet and by adding 40 square feet would bring them in line with other municipality's maximum unit sizes.

\section{Effectiveness}

The City of Vancouver developed laneway housing as part of their Eco-Density initiative which aimed to add density in single-family neighbourhoods in a sustainable way. They initially permitted laneway houses to be built on $90 \%$ of residential lots and recently have allowed them to be built on all single-family properties in addition to providing a density bonus of 0.16FSR for anyone interested in building a laneway house. Other density promoting regulations include allowing a property to have both a secondary suite and laneway house for a potential of 3 units on one singlefamily residential property while only providing 1 on-site parking space. Owners of the property are also not required to live on the property which encourages more investment and uptake, allowing

for additional infill options. Council, and for the most part the community, had an aggressive vision to add density in single family neighbourhoods and these four provisions have been effective in achieving their housing goals. To date Vancouver has issued approximately 1,300 permits for 
laneway houses and that number is increasing at a rate faster than it has in the past five years (Planner D, 2014).

The City of North Vancouver has a number of residential land use objectives in their Official Community Plan (OCP), some of which have links to laneway housing. Section 5.7.1 of the OCP states that the CNV should, " ...provide a range of housing densities, diversified in type, cost and location, to accommodate the diverse needs of the community." Other stated goals of coach housing in the $\mathrm{CNV}$ include providing a range of tenure types to increase current rental stock (Planner C, 2014). Laneway housing has not been used as the key driver for achieving these housing goals however it has been linked to addressing a portion of the problem. The City of North Vancouver staff and Council responded with a unique, two-tier approach with one storey laneway houses being Level-A and two storey being Level-B. Coach houses can only be used as rental properties and the owner must reside on the property. Currently a coach house cannot be built on a property with a secondary suite because initially coach housing was not seen as a way to increase overall density in the CNV. However a Draft Official Community Plan is being proposed with changes that will permit both secondary suites and coach houses on a single property as well as speeding up the Level-A coach house applications (combine Development Permit and Building Permit Application). To date the City of North Vancouver has approved 14 Level-A and 13 Level-B coach houses since 2010 and proposed changes are expected to increase uptake.

The District of West Vancouver is currently in the process of seeking community input on proposed coach house policies and guidelines which were described in a staff report presented to Council on November 18, 2013. By permitting the development of coach house the District of West Vancouver aims to address Principle \#3 of their Official Community Plan which is to, "provide for a diversity of housing types to accommodate a balanced and diverse population in terms of age, ability, income and household type". Simply put they are looking to provide other forms of housing outside of the large, single-family households which comprises $60 \%$ of all homes and $90 \%$ of all developed land area. Also West Vancouver wants to provide opportunities for older residents to downsize (currently $60 \%$ of population is over 40 years old) into smaller housing units on their property. So what is West Vancouver proposing in their laneway housing guidelines to ensure they will meet these objectives? Maximum coach house size of 1,200 square feet seems reasonable as many current home owners have large homes/properties and downsizing into a 900 square foot coach house may not be an attractive option. Also because most single-family properties are so large 
extra density will likely be leftover to accommodate 1,200 sf coach houses. They are not promoting coach housing as a way to increase density and therefore have not provided additional FSR and are not allowing them on sites with pre-existing secondary suites. Uptake numbers are not available since the Official Community Plan amendment and Zoning Bylaw amendments will not be passed by Council until community consultation has been undertaken. Based on the initial community feedback from questionnaires and survey's approximately $60 \%$ of residents support the idea of coach house construction occurring in their neighbourhood (West Vancouver Staff Report, 2013).

The District of North Vancouver is at the infant stages of laneway housing policy formulation with only a preliminary discussion paper being presented to Council in late 2013. While the OCP adopted in 2011 identified the need to diversify housing stock, increase rental stock and to seek ways to encourage young families to move into the community and to support older residents who want to age-in-place, Council wants to establish a restricted or gradual entry type of coach house program so as not to cause existing property owners concerns over loss of privacy or other perceived negative impacts (Planner B, 2014). Currently the DNV has one in four residents over the age of 55 and a shrinking number of young people/families calling the municipality home. The other major issue outlined in their Official Community Plan is the lack of housing diversity with roughly $70 \%$ of housing in the form of detached homes and 10\% of those homes only having one person living in them. With a vacancy rate of purpose built rental stock of near $0.9 \%$ in 2011 and limited new rental options, laneway housing is seen as part of the solution to housing diversity, age-in-place options, opportunities for multigenerational families living in the District and increasing the supply of rental stock (District of North Vancouver Official Community Plan, 2011). Since the policy has not yet been adopted there are no uptake numbers to officially examine how well the community is responding to the new housing policy. Based on an analysis of their discussion paper there are a number of regulations that would appear to limit the uptake to be expected such as the lot restrictions (e.g. only permitted on lots 50 feet or wider on a lane or 10,000 square feet without a lane) and not allowing properties with an existing secondary suite to also build a coach house (See Appendix A). On the other hand, since they are proposing a Development Permit Process which is less expensive (\$900) and relatively faster (density and use are cannot be varied), they still have a strong chance at meeting their housing goals through laneway housing development. The main barrier is the requirement of three parking spots required on a single-family lot with a coach house which could pose design and siting issues that may eliminate the smaller lots (4,000 square feet) and 
force additional density onto the second storey and decreasing the development of one-storey units on medium sized lots (5,000 to 10,000 square feet).

\section{Suitability}

Community acceptance of laneway housing is a determining factor for whether this form of housing is suitable for a jurisdiction. All four municipalities have (or will be required to) undertaken extensive public consultation to gauge community attitudes. City of North Vancouver residents have expressed that they are happy to have additional development options available to them on their property while issues of overlook and neighbour infringement are not large concerns due to Council approving every Level-B coach house thus far (Planner C, 2014). The District of North Vancouver is currently developing the policy in response to positive feedback heard by the community in their Official Community Plan consultations and interest expressed at various community meetings. Therefore laneway housing, at this point, has strong community support for both the District and City of North Vancouver. West Vancouver conducted a number of community consultation meetings, expert panels and questionnaires and found $78 \%$ of the community supported coach housing as an appropriate housing option for West Vancouver (Staff Report, Sept. 2013). Finally in 2010-2011 Vancouver experience a number of complaints regarding laneway houses related to blocking views and adding too much density. This can be directly related to two storey units being built on 33 foot wide lots. However, since changes to the policy have encouraged more one storey units community complaints have tapered off (Planner D, 2014). Overall laneway housing is suitable for each municipality based on community acceptance of the idea. One observation that can be made from this is that laneway housing is often accepted by municipalities they are being proposed in. If they are met with opposition, staff and Council can make necessary changes to design guidelines and criteria to ensure the community concerns are mitigated and stated housing goals are achieved.

The natural topography of the land a municipalities boundaries reside within can also play a role in how suitable laneway housing is. Although it is not a determining factor that excludes communities that are on a mountainside or have a number of steep hills, it simply allows for easier construction and implementation in areas that are relatively flat. For example, the City of North Vancouver is located primarily on two benches at the base of a mountain with many properties having access to a lane. Where sloping terrain comes into play solutions such as large retaining walls 
can be used which may be more expensive for a property owner but still allows the construction of laneway homes (See Figure H and Figure I). The District of North Vancouver and West Vancouver are even more mountainous and the overall costs of laneway construction there will be more expensive as a result. Therefore a conclusion could be made that laneway housing is suitable for municipalities with mountainous topography only where real estate and personal income levels are sufficiently high as additional construction costs are often incurred. Vancouver has seen a high number of laneway houses built partially due to their policy regulations (additional density provided) and partially due to their flat topography allowing for easier construction (See Figure J).

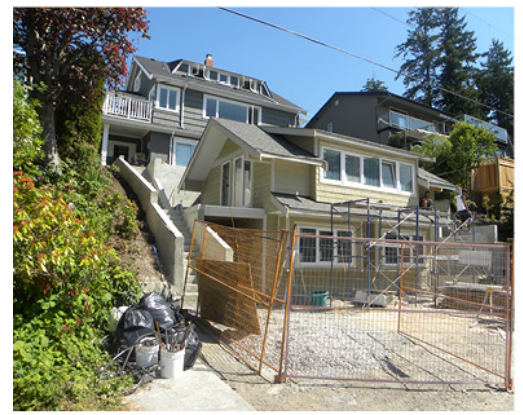

Figure H: Finley, B. Coach House in the CNV. City of North Vancouver.

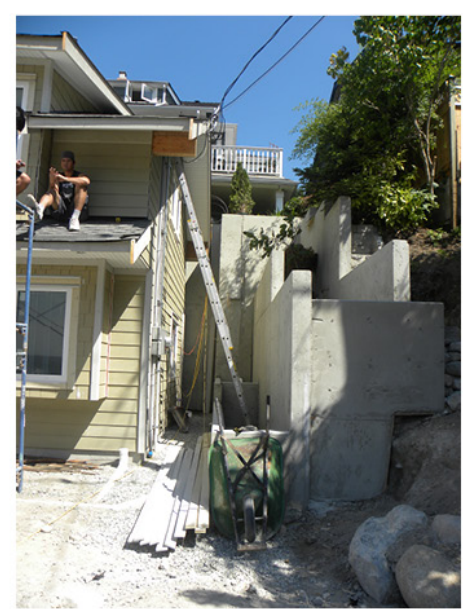

Figure I: Finley, B. Coach House in the CNV. City of North Vancouver.

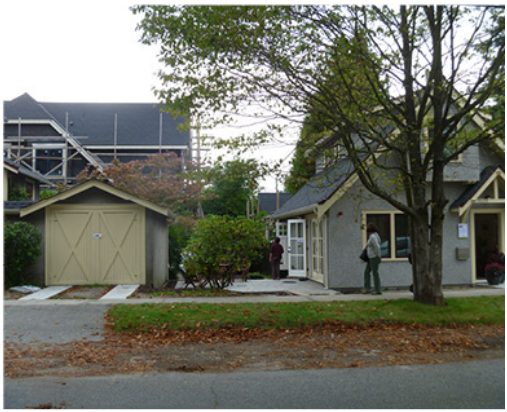

Figure J: Vancouver, C. o. Laneway House in Vancouver. City of Vancouver

Aside from topography, another physical characteristic that can make laneway housing more suitable for a municipality is their pattern of development. It is easier and more appropriate for municipalities with grid development and lane systems to adopt laneway housing policy. The District of North Vancouver and West Vancouver have more curvilinear patterns and fewer grid and lane patterns which is likely the reason why the DNV is taking a conservative approach to their laneway program. It will allow that municipality to see how the first wave of applications are being applied to their unique development pattern, specifically the regulation requiring a property to reside on a lane or be over 10,000 square feet. Very few properties currently reside on a lane and therefore future changes may see the DNV decrease the 10,000 square foot requirement gradually to allow more properties to become eligible for laneway house construction. The City of North Vancouver, and 
even more so in Vancouver, have a large number of lanes and a grid network of streets. Vancouver requires lane access to build a laneway house however this does not affect the total number of eligible lots because the extensive lane system already in place encompassed a large number of properties. The City of North Vancouver however does not require a lane even though most portions of the City have lane systems. Since the single-family zones of the CNV covers minimal land area they chose not to discount properties without lanes and instead will work with applicants to make it work (to date all coach houses in the CNV are on laneways). The District of North Vancouver and West Vancouver are still in the early stages of their policy and the few laneway homes have been built in those jurisdictions have been done by rezoning. Therefore their level of success of these new programs is yet to be determined and their unique street patterns may prove to be an influential factor.

Lot sizes and the overall pattern of subdivision can make laneway housing more suitable and easier to implement in a given jurisdiction. For example the District of North Vancouver and West Vancouver have large lots and a majority of lot frontages over 50 feet therefore laneway housing may be more suitable for these communities because lot sizes are larger, overlook is less likely and additional density is more likely to be available. The City of North Vancouver has a mixture of lot frontages with few 33 foot wide lots and a majority being larger. Currently laneway housing is permitted on 33 foot frontages with many regulations to reduce overlook however due to the high number of regulations few have developed. Level-A coach houses require development permits and if there is no left-over density (more likely with 33 foot lots) then no coach house can be built. Level-B coach houses require rezoning and technically the owner could ask for any density however this adds more building bulk to a neighbourhood and encroachment onto neighbours is much more likely. Lot frontages should be increased to 40-50 feet or additional density may be needed to 33 foot frontages desiring to build a Level-A coach house to promote one storey units. Vancouver has a high number of 33 foot lot frontages and permits laneway homes on lots, if proven suitable, with as small as 24 foot frontages. One storey units are strongly encouraged on these lots and additional density has been provided in order to find any success with the program as all lots were considered as being already developed to the maximum FSR. Overall Vancouver understood their pattern of development and made all the necessary legislative decisions to promote laneway development. In theory the District of North Vancouver and West Vancouver have taken the initial legislative steps 
in relation to their lot pattern of subdivision to provide coach house development the best opportunity to succeed.

Finally a distinction can be made between the type of coach house programs that allow for the sale of the unit and those that restrict the unit to being part of the single property. Both approaches may be referred to as "infill development" however they provide different types of housing along the housing continuum - owned units v. rental units for example. As well, a municipality must decide whether coach housing will be used for infill situations where the principle house is retained and a coach house is added, allowed only when the lot is being totally re-developed with the construction of both a new house and coach house at the same time or just permitted for Greenfield development. The City of Vancouver and the City and District of North Vancouver programs allow coach houses to be built as "add-ons" to existing lot development or redeveloped with the entire property whereas the West Vancouver program (for now) is looking to use coach house development as part of their infill strategy for both rental and ownership approaches. A great example is the Hollyburn Mews project in West Vancouver which developed a collection of duplex homes and coach houses to permit denser forms of infill in single-family neighbourhoods. Both options result in similar built form outcomes and are suitable for all municipalities as they are relatively built out with no Greenfield development opportunities as illustrated earlier in Surrey, BC (See Figure K and Figure L). Some municipalities have decided to allow Greenfield developments the opportunity to build coach houses in conjunction with new single family homes. The outcomes are staggeringly different from infill and single-lot redevelopment and can result in laneways with little character, resembling a long, blank wall of garage doors (See Figure M).

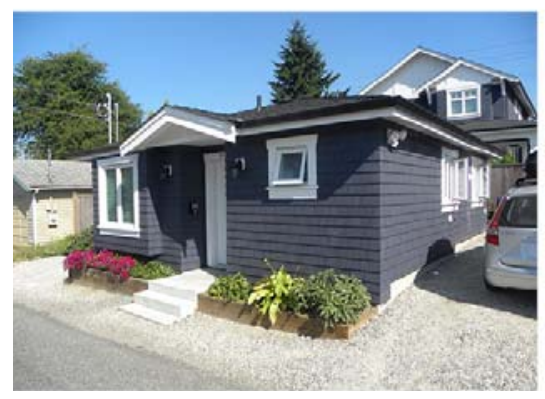

Figure K: Finley, B. Coach House in the CNV. City of North Vancouver.

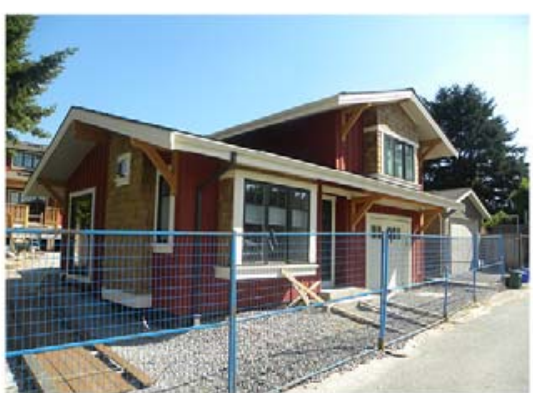

Figure L: Finley, B. Coach House in the CNV. City of North Vancouver.

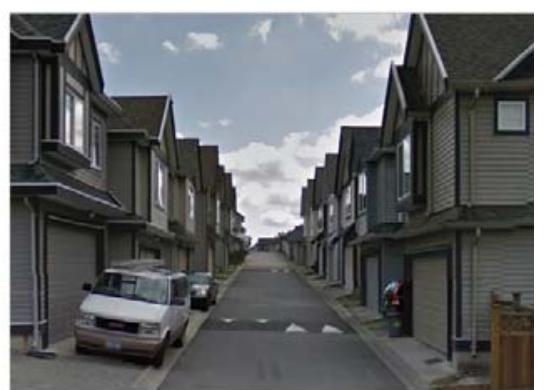

Figure M: Maps, G. East Clayton Coach Houses. Surrey. 


\section{Administrative Process}

Both the City of North Vancouver and West Vancouver are using or proposing to use a 50 meter notification radius to advise neighbouring property owners of pending Development Permit applications pertaining to laneway housing development. With a number of extremely large lots in West Vancouver the notification of 50 meters is unlikely to reach all affected properties and is seen as not large enough to keep community members informed of changes coming to their neighbourhood. The City of Vancouver does not send any formal notification to residents at all when issuing a Development Permit for a laneway house, resulting in many neighbours being upset over the unexpected construction occurring. The District of North Vancouver is currently proposing a process with formal notification within a 50 meter radius as well. This typically notifies adjacent neighbours on both sides and three properties across the lane or the rear property line if there is no lane. Based on a fair, equitable planning process Vancouver seems to come up short while all other municipalities keep neighbours informed and consistently apply the Local Planning Act's notification requirements.

Overall process costs and time associated with going through the application process can hinder or expedite the amount of laneway homes built. By strictly examining the application costs all municipalities are fairly equal being around $\$ 1,000$. Also there are similarities with the overall time of the application process ranging from 4-8 months depending on the size of the laneway house being proposed. However, when examining uptake numbers there is a clear distinction between the City of Vancouver (1,300 applications) and the other municipalities (27 applications). Currently West Vancouver and the District of North Vancouver have no coach houses built but their numbers are expected to resemble those of the City of North Vancouver (See Appendix A). The difference is due to the level of political support and the purpose of Vancouver's program. In Vancouver the majority political party supported the eco-density platform and delegated the approving authority to staff with a clear mandate to allow this form of development, despite the lack of neighbour support (in some cases). Whereas, all other suburban municipalities face different political situations and have different goals for the laneway housing program such as diversifying housing typologies and providing opportunities to age-in-place. Therefore processing costs and time do not act as catalytic factors when determining uptake numbers, rather political vision of council, housing goals of the municipality, individual owner needs (bringing the family back together) and the potential (especially in Vancouver) for economic return have a greater impact on laneway house construction. 


\subsection{Conclusion and Recommendations}

Over the past decade the Canadian housing market has experienced a dramatic increase in the cost of housing, especially in major metropolitan regions such as the GTA and Metro Vancouver. Increase in demand and decrease in supply of developable land have more than doubled the average price of single-family homes in these areas. In response developers have built upward with condominium towers and mid-rise apartments in order to make the development of such highcost land profitable. However other options exist to accommodate population growth in these areas that can add to the diversity of housing types within a municipality, maintaining the character of single-family neighbourhoods and offer more affordable single-family living options.

A key takeaway from this analysis is to understand why a municipality pursued the planning of laneway housing in the first place as a way to evaluate whether their policy has been effective. The summary chart outlined in this study illustrates that all municipalities have developed effective laneway housing programs because they developed clear laneway housing objectives related to their overall housing goals (Vancouver to increase density and others to add diversity to housing stock, increase rental units and provide options to families/owners), adopted regulations that encouraged this form of development and used laneway housing as a means to achieve a portion their housing goals. The concept of living on a laneway, in the backyard of another person requires an immense amount of research and analysis in order to determine the best policy direction a given municipality should go in.

In terms of Livability, the City of Vancouver had the strongest Design Guidelines that visually represented how livability will be achieved and enhanced through laneway housing. All other municipalities did incorporate requirements for landscaping and deck orientation however Vancouver's was the most comprehensive and understandable for potential laneway house developers. The District of North Vancouver and West Vancouver could still develop a strong set of visual Design Guidelines however as of now nothing has been formally available. By evaluating the current (or proposed) laneway housing programs for the four municipalities against five laneway housing principles there are two distinct areas where two municipalities have the ability to improve their policy. There are also many aspects we can learn about conventional (grid network) and unconventional (suburban, irregular streets) patterns of development and their relationship to laneway housing. 


\section{D}

Livability of Laneway Housing
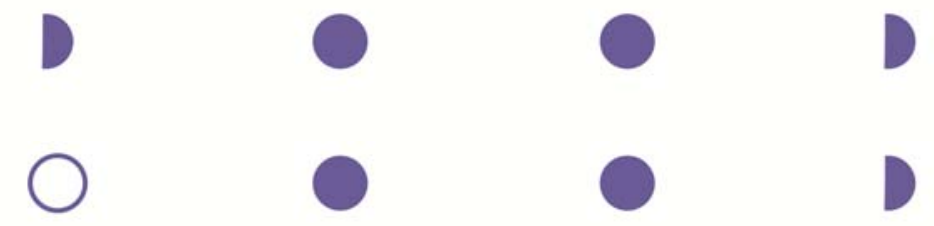

Effectiveness

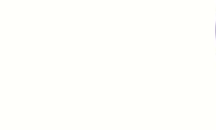

Suitability

Adminstrative Process
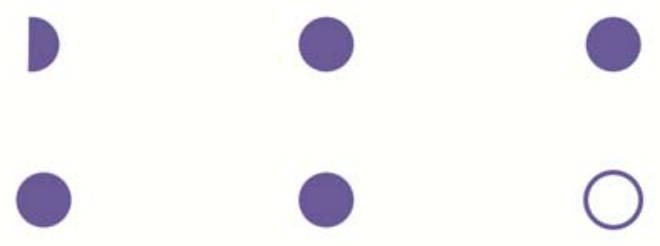

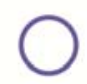

Area to Improve

Acceptable

Figure N: Finley, B. Summary Chart of Laneway Housing Policy Analysis

\subsection{Vancouver}

Since Vancouver's administrative process does not require a formal notification to neighbours when a laneway housing Development Permit is applied for so the ability of the policy to be compatible with neighbours is not considered fair, equitable or equally applied across all jurisdictions. Neighbour complaints and unsuspecting construction in residential streets greatly impacts adjacent residents and because no notification process is in place there are often complaints from residents to Council. The system relies on staff to account for the impacts on a neighbour which is not an ideal model as they are not the ones living next door to a laneway house which may be causing issues to the adjacent neighbours. A simple way to mitigate neighbour complaints is to require proof that the homeowner themselves have consulted with neighbours before applying for the Development Permit (as is the case for the City of North Vancouver). This way no formal 
changes need to be made to the Development Permit process and neighbours are still being informed regarding developments occurring in their area.

\subsection{District of North Vancouver}

The program that is being proposed for the District of North Vancouver is too limited to be very effective at this point in time. An estimated 5-25 units per year is not adding significantly to the rental housing stock or diversifying the typology of housing enough. The restrictive application which does not allow additional density or coach houses with a secondary suite and requires laneway access for properties smaller than 10,000 square feet. These factors limit the ability to achieve their stated goal which includes the promotion of aging in place however the program does reflect the municipality's desire to start with a gradual entry type of program.

As well, the DNV has proven through their initial criteria that factors such as uneven topography, steep sloping site and irregular lot sizes are not determining factors that control whether

coach housing is suitable or not suitable for a particular area. Irregular geography is accounted for by allowing large properties (over 10,000 square feet) to construct a coach house without requiring lane access and the fact that they are so large provide an opportunity to overcome steep slopes. When analyzed with the conventional form of suitability the DNV program inherently falls short due to its geographical location and limited number of laneways. However the inclusion of larger lots is an attempt to permit more properties for the program by recognizing the factors that make this municipality unique. Since the DNV is planning to review the program after a two to three year period a possible revision could be to permit smaller lots without lanes to construct coach houses as a way to be further effective and achieve desired goals.

\subsection{City of North Vancouver}

Like Vancouver the City of North Vancouver's program is based on a grid system and applicable to all RS zones. The design guidelines and criteria are acceptable with understanding documents that clearly articulate the CNV's requirements while the administrative process is strong as larger coach houses require Council approval allowing for more public input and ensuring neighbourhood compliance. By not allowing a density bonus livability is enhanced and privacy concerns are mitigated while the 1,000 square foot maximum unit size is acceptable due to the prevalence of 50x120 foot lots. When compared to the District of North and West Vancouver the requirement of 
two parking spaces seems suitable as they are more centrally located and better serviced by transit. The somewhat slow uptake of coach house construction in the CNV could be attributed to residents waiting on the draft Official Community Plan to be approved that could allow the construction of both a coach house and secondary suite on a single-family lot. This would give more economic incentive that was not been available previously and may garner more development applications. The City of North Vancouver represents a coach housing program for a small city, mostly on a grid with many sloping sites and laneways. This is an excellent program to emulate for other cities in Canada to learn from when looking to export a laneway housing program.

\subsection{District of West Vancouver}

The District of West Vancouver has very similar issues as the District of North Vancouver with a high prevalence of irregular lot shapes, limited laneways and sloping natural landscapes creating a setting that is not ideally suitable for laneway housing however they have shown (like the DNV) that coach housing programs can be developed in a suburban community that does not have a grid system. By not requiring lane access West Vancouver has attempted to qualify more properties for the program and taken into account the pattern of development, particularly the limited laneway network and provided themselves the opportunity to be more effective in reaching their housing goals which is mainly to diversify their housing stock. However for this to be successful one suggestion would be to incorporate strong visual and technical examples of how a laneway house can be oriented on a number of different lot types so it is easier understand for applicants on sloping sites and strengthen the fact that coach houses are suitable for their topography. For example, illustrating access from a shared driveway versus from a lane or the increased construction costs for developing a laneway house if the property resides sloping site. Currently the West Vancouver program is subtlety setting itself up to allow both coach houses to be rented in single-family areas and using them as an element in multi-family areas that can be sold separately by framing coach housing as part of an infill strategy. However they are focusing on the rental option first to examine the initial uptake and outcomes. This program, along with the District of North Vancouver, both illustrate that you do not need a grid system to make coach housing a part of the housing continuum and that it can be suitable for both conventional and unconventional patterns of development.

Based on this analysis laneway housing is not the ideal way to reduce income polarization and ensure increased services are being provided to low-income households as laneway homes are 
not typically seen as affordable housing forms. Hulchanski’s (2010) fragmented city (Toronto) is a model whereby income polarization occurs because lower income individuals are pushed to the edges of municipal boundaries thus receiving fewer services. Laneway housing is not expected to change that situation as it is likely to be more successful in higher income communities as property owners will have surplus income to invest in building a backyard home. The rents for laneway houses, as evidenced in Vancouver, are still high per square foot however lower than condominium and neighbouring single-family rents. Current coach house rents are well over the accepted definition of affordable housing being 30\% of a household's gross income (CMHC, 2006). More affordable rental units can be built by developing a policy to allow the construction of secondary suites in jurisdictions where it is not currently allowed. In Greater Vancouver currently 24\% of all single family dwellings already have secondary suites as mortgage helpers, which provide more affordable housing as those units are far less expensive to build (Metro Vancouver, 2009). However there is an argument that laneway housing does provide affordable (rental) housing for those who desire to live in ground oriented single-family neighbourhoods given that the alternative is to purchase a single family home which is typically out of reach for tenants but which may increase the affordability to the owner. Therefore laneway housing can make living in single-family neighbourhoods more affordable as the cost to construct a unit is comparable to the cost of purchasing a new one bedroom apartment. Aligning these factors with their ability to increase housing stock in desirable neighbourhoods laneway homes have the potential to increase housing diversity in various communities.

\subsection{Policy Implications}

Through this analysis there are a number of conclusions that can be drawn from each municipality's laneway housing policy and be applied to other jurisdictions. One of the main aims of this paper was to first examine how other municipalities have developed their policy, learn from what made their programs successful and provide a list of recommendations for future municipalities looking to develop their own laneway housing policies. Through the comprehensive analysis of four Western Canadian municipalities a it has been determined that in order for a laneway housing policy to have the greatest opportunity to be successful it must:

- Have a clearly stated goal it is looking to achieve (density, diversify housing types). 
- Develop a set of criteria that is researched and reflects the municipality's topography and development pattern.

- Create design guidelines prior to community consultation to promote understanding by both residents and potential developers. Also ensure the guidelines have strong visuals that display how common arguments against laneway housing will be mitigated (window placements, landscaping).

- Determine an approval process that will not hinder development and allow it to succeed without too many constraints (less cost and faster application process).

- Garner strong community and council support by using visual displays from design guidelines at community consultation meetings.

- Monitor uptake and the total number of units being constructed and consult the community on potential changes to the policy after a pre-determined time period.

This analysis of four different laneway housing programs in British Columbia has proven that municipalities can build laneway houses on a grid or curvilinear street network as well as on flat or mountainous topography. It has also proven that laneway homes can be utilized by larger metropolitan cities or by smaller, suburban communities to achieve a variety of housing goals from increasing density or providing additional options for families. Overall laneway housing is a flexible option for municipalities and can be tailored to address specific needs within individual communities. 


\section{Appendix A- District of North Vancouver Coach House Demand Study}

\section{APPENDIX C: Coach House Uptake Demand}

Two methods of analysis were used in order to estimate how many coach house applications might be received by Council if the program moves forward. The first method looked at the rate of uptake in two other municipalities the City of Vancouver and the City of North Vancouver. In the City of Vancouver, 59,000 single family lots qualify for coach housing and approximately 300 applications are approved by staff annually. The uptake ratio is therefore, 0.0051 . In the City of North Vancouver, $\mathbf{4 1 7 8}$ single family lots qualify and fourteen applications have been approved annually. Of these applications, six have been staff decisions and eight have been Council decisions (involving the larger units). The combined uptake ratio is, therefore, 0.0034 for both types of applications but only 0.0019 for those applications requiring rezoning and considered by City Council. As the City Council application ratio is closest to the proposed District of North Vancouver process, staff might expect:

- Elght coach house rezoning applications per year if the program includes lots 50 feet or wider on a lane or a corner lot 50 feet or wider (4,270 lots), $\mathbf{0 R}$,

- Fourteen coach house rezoning applications per year if the program also includes large lots between 10,000 and $20,000 \mathrm{ft}^{2}$. (3,161 lots).

The second method of analysis looks at the number of properties that meet the Lot Size criteria and then considers three new criteria-the presence of secondary suite, the development capacity available under existing zoning and whether or not the property was in the Streamside Protection DPA. This capacity to build the Coach House is split into 2 categories of over or under $500 \mathrm{ft}^{2}$. In this method all the lots meeting the minimum size criteria were included (7431) as only 657 do not have a suite and do have the surplus capacity to build a Coach House larger than $500 \mathrm{ft}^{2}$. and were not in the DP area. There are an additional 6888 properties that met these additional conditions. Given the expense involved in the process and the potential servicing and development costs for such small units staff do not believe many of these owners will be interested in applying during the Stage I period. However, some owners may be interested and because of the potential for error in estimating house sizes from existing information sources, there might be an additional 10 to 20 percent of these properties that could also be suitable candidates. This would bring the total number of qualifying lots to between 1068 and 1479 . When the City Council application ratio is applied to these numbers it could be expected that 2 or 3 Coach House rezoning applications per year might. be generated during the Stage 1 Interim period of the District's process.

Given the numbers of applications estimated above it is expected that the District of North Vancouver will see a very gradual uptake of the coach house development with the current approach and selection criteria. Process and potential utility hook-up and site servicing costs are expected to deter the individual property owners from building many of these types of dwellings. This gradual uptake will allow Council and staff to see which criteria are best suited for our unique topography and development pattern and which ones may need altering or eliminating all together.

\begin{tabular}{|c|c|c|c|c|c|}
\hline & & \multicolumn{2}{|c|}{$\begin{array}{l}500+\mathrm{ft}^{2} \text { of buildout } \\
\text { available }\end{array}$} & \multicolumn{2}{|c|}{$\begin{array}{l}\text { Estimate }<500 \mathrm{ft}^{2} \text { of } \\
\text { buildout avallable }\end{array}$} \\
\hline & & No Suite & $\begin{array}{l}\text { Existing } \\
\text { Suite }\end{array}$ & No Suite & $\begin{array}{l}\text { Existing } \\
\text { Suite }\end{array}$ \\
\hline \multirow{3}{*}{$5,000-10,000 \mathrm{ft}^{2}$ on Lanes or Corners } & On Lane & 55 & 27 & 1057 & 603 \\
\hline & Corner Lots & 59 & 12 & 1718 & 563 \\
\hline & Sub TOTAL & 114 & 39 & 2775 & 1166 \\
\hline \multicolumn{2}{|l|}{$10,000-20,000 \mathrm{ft}^{2}$ Lots } & 543 & 152 & 1338 & 383 \\
\hline \multicolumn{2}{|l|}{ TOTAL LOTS BY QUALIFIED POTENTIAL } & 657 & Dlsquallified & 4113* & Dlsquallfied \\
\hline GRAND TOTAL QUALIFIED LOTS & \multicolumn{5}{|c|}{$657+411=1068$} \\
\hline
\end{tabular}

*Estlmate that $10 \%$ of these lots may quallfy and be Interested In coach House development dlsplte only belng able to bulld less than $500 \mathrm{ft}^{2}$ units See Map 1 for locatlons of these Propertles 


\section{Appendix B- Interview Guide}

Introduction:

- Introduce myself and outline major research components of MRP

o The morphology of housing across Canada, particularly in Urban centres with focus on the changing physical built form of housing and the factors that have played a role in that change.

0 The growing use of laneway housing, its benefits and critiques.

o Case study analysis of three municipalities Laneway Housing Policies including Vancouver, CNV and the DNV (I worked on this so I have information I can use). I really am interested in:

- Inform participants of their rights

- Signature of participant's consent form

\section{Questions}

- In your opinion, do you think accessory dwelling units are a beneficial form of housing for a municipality? Why or why not?

- In your experience, what do you believe are some of the key criteria or regulations that should be included when developing an accessory dwelling unit policy?

- Why you think Western Canada (specifically the City of Vancouver and several other surrounding municipalities have been trailblazers for accessory dwelling unit (laneway/coach/carriage/backyard cottage housing) policy? Why do you think it hasn't happened in Toronto?

- Describe your experience with Accessory Dwelling Unit Policy. Can you elaborate on any particular reasons how and why it developed in your municipality? In other words the trigger that sparked its adoption?

- In your opinion, how have Developers reacted to Accessory Dwelling Unit policies in your municipality? Have they had suggestions for improvements? (particularly the approval process or design guidelines)

- What has been the reaction from residents to Accessory Dwelling Units being built in their neighbourhoods? What are the common compliments and concerns raised?

o What was the strategy used to gain community input?

- Do you think having robust design guidelines are important for municipalities to help control design and form of Accessory Dwelling Units? Or would a more flexible, case-bycase design standard be better?

- Is there anything you would like to add or any questions that I haven't asked you about that I should have?

Concluding Remarks: Thank participants and allow for post interview discussion 


\section{Reference List}

Affordability and Choice Today (ACT), (2003). A Study of Laneway Housing in Toronto, prepared by Stinson, J., \& Terence V. E.

Canadian Mortgage and Housing Corporation, (2006). Housing in Canada Online: Definitions and Variables.

Canadian Institute of Planners, (2014). Code of Professional Conduct. Retrieved from: https://www.cipicu.ca/web/la/en/pa/C59DDE35F1184B5E89385E53506C19F8/template.asp

Canadian Mortgage and Housing Corporation, (2009). Livable Lanes: A study of Laneway Infill Housing in Vancouver and Other Growing B.C. Communities.

Canadian Mortgage and Housing Corporation, (2013). Local condo starts drop, laneway home construction surges. Retrieved from: http://www.news1130.com/2014/01/09/local-condostarts-drop-laneway-home-construction-surge/

City of Vancouver, (2013). Laneway Housing How-To Guide. Retrieved from: http://vancouver.ca/files/cov/laneway-housing-howto-guide.pdf

City of North Vancouver, (2010). Level-A Accessory Coach House Development Permit Guidelines. Retrieved from:

http://www.cnv.org/ /media/City\%20of\%20North\%20Vancouver/Documents/Develop ment $\% 20$ Applications/Level-

A $\% 20$ Accessory $\% 20$ Coach $\% 20$ House $\% 20$ Development $\% 20$ Permit $\% 20$ Guidelines.ashx

City of North Vancouver, (2010). Level-B Accessory Coach House Development Permit Guidelines. Retrieved from:

http://www.cnv.org/ /media/City\%20of\%20North\%20Vancouver/Documents/Develop ment $\% 20$ Applications/Level-

B\%20Accessory $\% 20$ Coach $\% 20$ House $\% 20$ Development $\% 20$ Permit $\% 20$ Guidelines.ashx

City of North Vancouver, (2002). Official Community Plan.

City of Toronto, (2006). Staff Report on the Construction of Housing in Laneways ALL

WARDS. Retrieved from:

http://www.toronto.ca/legdocs/2006/agendas/committees/wks/wks060705/it007b.pdf

City of Toronto, (2006). Staff Report on the Construction of Housing in Laneways ALL

WARDS. Retrieved from:

http://www.toronto.ca/legdocs/2006/agendas/committees/wks/wks060705/it007b.pdf

District of West Vancouver, (2004). Official Community Plan. 
District of North Vancouver, (2011). Official Community Plan.

District of West Vancouver, (2013). Staff Report on Proposed Coach House Implementation. Retrieved from: http://westvancouver.ca/sites/default/files/dwv/councilagendas/2013/nov/18/13nov18-10\%20OT.pdf

District of Maple Ridge, (2007). A Discussion Paper for Maple Ridge. Detached Garden Suites: Issues and Options. Retrieved from: http://www.mapleridge.ca/DocumentCenter/View/782

District of North Vancouver, (2013). Exploring Coach Houses in the District of North Vancouver: A Discussion Paper.

HDR. Greater Toronto Transportation Authority, (2008). Costs of Road Congestion in the Greater Toronto and Hamilton Area.

Hulchanski, D., (2010). The Three Cities Within Toronto: Income Polarization Among Toronto’s Neighbourhoods, 1907-2005). University of Toronto.

Lucy, W. H., \& Phillips, D. L., (2006). Tomorrow's Cities, Tomorrow's Suburbs. American Planning Association.

Macdonald, D., (2010). Canada's Housing Bubble: An Accident Waiting to Happen. Canadian Centre for Policy Alternatives.

Metro Vancouver and Ministry of Community Services, Province of British Columbia, (2007). Increasing Housing Density in Single Detached Neighbourhoods, prepared by Coriolus Consulting Corporation.

Moore, E., \& Skaburskis, A., (2004). Canada's Increasing Housing Affordability Burdens. Housing Studies, 19(3), p.395-413.

MLS, (2013). Home Price Index. Retrieved from: http://homepriceindex.ca/hpi_home_en.html.

Metro Vancouver, (2009). Metro Vancouver Housing Data Book. Retrieved from: http:// www.metrovancouver.org/planning/development/ housingdiversity/HousingDataBookDoc uments/MV_Housing_Data_Book.pdf

Neptis Foundation, (2006). Economic Influences on Population Growth and Housing Demand in the Greater Golden Horseshoe, prepared by Will Dunning.

Organisation for Economic Co-Operation and Development. (2009). OECD territorial reviews:

Toronto Canada. OECD Publishing.

Ontario Ministry of Municipal Affairs and Housing, (2011). Strong Communities through Affordable Housing Act. Queens Printer for Ontario. 
Pomeroy, S., (2001). Toward a Comprehensive Affordable Housing Strategy for Canada. Caledon Institute of Social Policy.

Statistics Canada, (2011). National Housing Survey: Condominium Dwellings in Canada.

Statistics Canada, (2012). Indicators of Well-being in Canada: Housing- Rental Vacancy Rates.

Statistics Canada, (2011). Immigration and Ethnocultural Diversity in Canada.

Statistics Canada, (2011). Census Metropolitan Area for Toronto.

Statistics Canada, (2011). Census Metropolitan Area for Vancouver.

Thomas, R., (2011). The Filipino case: Insights into choice and resiliency among immigrants in Toronto. UBC Ph.D. Dissertation. Vancouver. 